\title{
Youth Livelihood Opportunities in Egypt
}

Safaa El-Kogali

Population Council

Nagah Hassan Al Bassusi

Follow this and additional works at: https://knowledgecommons.popcouncil.org/departments_sbsr-pgy

Part of the Demography, Population, and Ecology Commons, Family, Life Course, and Society Commons, Growth and Development Commons, and the Work, Economy and Organizations Commons How does access to this work benefit you? Let us know!

\section{Recommended Citation}

El-Kogali, Safaa and Nagah Hassan Al Bassusi. 2001. "Youth Livelihood Opportunities in Egypt." Cairo: Population Council. 


\title{
Youth Livelihood Opportunities in Egypt
}

\author{
Safaa El-Tayeb El-Kogali \\ and
}

Nagah Hassan Al-Bassusi

Population Council, Cairo 


\section{Q. Population Council \\ One Dag Hammarskiold Plaza. New York. New York 10017 phone: 212-339-0500 Hacsimile: 212-755-6052 \\ Email: pubinfoepopcouncil ors http:/www popcouncilors}

The Population Council seeks to improve the well-being and reproductive health of current and future generations around the world and to help achieve a humane, equitable balance between people and resources. The Council, a nonprofit, non-governmental research organization established in 1952, has a multinational board of trustees; its New York headquarters supports a global network of regional and country offices.

The Council's work on Youth Livelihoods Opportunities in Egypt was supported by the U.S. Agency for International Development (USAID), Cooperative Agreement (USAID/HRN-A00-99-00010); the International Development Research Centre (IDRC), Youth Livelihoods Opportunities grant, number 04384/98-0227; and the Rockefeller Foundation's Transitions to Adulthood: Opportunities and Risks for the Next Generation grant, RF99009\#214.

For further information and copies of this publication, please contact:

The Population Council

Regional Office for West Asia and North Africa

P.O. Box 115

Dokki, Giza 12211

Egypt

Telephone 20-2-570-1733

Fax: 20-2-570-1804 


\title{
Youth Livelihood Opportunities in Egypt
}

\author{
Safaa El-Tayeb El-Kogali \\ and
}

Nagah Hassan Al-Bassusi

Safaa El-Tayeb El-Kogali was a former Consultant to the Population Council, Cairo, Egypt. Nagah Hassan Al-Bassusi is a Consultant to the Population Council, Cairo, Egypt. 
Table of Contents

Acknowledgements

Preface

Chapter 1: A Conceptual Framework

Introduction

Background

Structure of the Labor Market

Economic Reform and Youth Opportunities

The Social Context of Work

Young women and livelihoods Opportunities

Conclusion

\section{Chapter 2: The Policy Context}

Introduction

Background

Privatization and Inv. Policies

Labor Laws

Women and policies

Conclusion

Chapter 3: Youth and the Labor Market, 1988-1998

Introduction

Background

Define, Data and Methodology

A profile of Youth in the Labor Force in Egypt

Evolving Opportunity in Labor Market

Conditions of work

Conclusion

Chapter 4: Opportunities and Work Conditions in the Private Sector

Introduction

Date and Methodology

Characters

Women's Perspective

Conclusion

Appendix

Bibliography 


\section{Acknowledgements}

This project has benefited enormously from its association with a number of individuals and institution. Foremost, we would like to thank the Economic Research Forum and the Central Agency for Mobilization and Statistics (CAPMAS) for allowing us the opportunity to include a special module in the Egypt Labor Market Survey of 1998 and for giving the Population Council generous and timely access to the data. In particular, we would like to thank Dr. Ragui Assaad for facilitating this collaboration and for his generous offer of time in responding to our many questions on the data. An illustrious advisory committee met on several occasions to guide the research process. We thank the members of the advisory committee for their valuable comments and their time.

This research was made possible by funds from the International Development Research Centre, Canada, the Rockefeller Foundation, and the United States Agency for International Development.

Safaa El-Tayeb El-Kogali thanks Dr. Barbara Ibrahim and Dr. Sajeda Amin at the Population Council for the opportunity to take part in this project and for their guidance and very useful comments in preparing these chapters. She also thanks Wesley Clark and Eldaw Suliman for their valuable comments. She notes her gratitude to Dr. Ragui Assaad for his continued teaching and guidance; and is glad to have worked with Nagah Hassan Al-Bassusi on this report - her insight was illuminating. Lastly, thanks to all the staff at the Population Council in New York and Cairo who provided valuable assistance during her research.

Nagah Hassan Al-Bassusi would like to acknowledge the young working women she met and for anonymity could not mention their real names in the study. She thanks them deeply for the time they gave to talk about their lives and reveal their personal feelings, during their weekends or after long working hours. They were capable and articulate in reflecting on their work experiences. She also thanks Dr. Atef Alam-Edeen and Mr. Magdy Kamal who introduced her to the selected sample. She is indebted to Mr. Willem Van Ekeleen from the ILO Cairo office for accepting to review the chapter and giving valuable feedback. She also thanks Dr. Hania El- Sholkamy and Dr. Karima Khalil, from the Population Council WANA office, for their insightful comments and Moushira Elgeziri, Sarah El-Deeb, and Hind Wassef for their continuous support. 


\section{Preface}

The Egyptian economy has been in the process of an ambitious reform program to facilitate its integration into a global economy since the beginning of the 1990's. The program has farreaching implications for growth, the future well-being of the population and for those who work in the labor market. This study, in keeping with a growing interest in the lives of young people in the country, explores the implications of economic reform for those who are entering the labor market in Egypt for the first time.

The current cohort of adolescents is the largest in history. As such they are also the largest cohort of entrants into the labor market. In addition to sheer size, the present cohort of new entrants in Egypt are more educated than ever before and many more women are coming out in search of work. Properly utilized, these characteristics can be an asset to the economy in promoting further growth. Without adequate job creation policies, however, rising youth unemployment could have a destabilizing effect.

This report presents evidence from a two year study of the opportunities and challenges facing young people age 15-24 in the labor market. It provides data on the size of the workforce, levels of employment, sectors of employment and nature of employment. Nationally representative data from 1988 and 1998 labor force surveys reveal trends in the labor market changes during the past decade. Through in-depth qualitative analysis, the report documents the experience of young female workers in the sectors of the economy that are expected to expand in an era of increasing globalization.

We hope that the analysis presented in this report will prove useful to policy makers, NGOs and researchers, as Egypt confronts the challenges of economic reform. Egypt's labor force is its largest asset and the ability to harness the potential and energy of young entrants holds the key to the country's future development.

Sajeda Amin

New York

Barbara Ibrahim

Cairo

September 2001 


\title{
Chapter One
}

\section{A Conceptual Framework}

\author{
Safaa El-Tayeb El-Kogali
}

\section{INTRODUCTION}

This report presents results from a quantitative and qualitative study on youth livelihood opportunities in Egypt. The study is motivated by growing evidence of increasing unemployment among the young at a time when new entrants into the labor force are also increasing at unprecedented rates. Egypt has a youth population of over 13 million aged 15 to 24 - over a fifth of the total population. They constitute the largest segment of the economically active population. Whether this bulge of young workers entering the labor force is a 'demographic gift' or a 'demographic burden' depends in large measure on the policies that are in place to guide their entry into the labor force, and their accumulation of human capital. Opportunity structures for youth at this transitional stage of their life will not only contribute to the economic and social development of the country, but also shape and influence all aspects of their lives as adults.

We are thus interested in knowing where job opportunities are increasing and who is finding work among the recent cohort of youth This study builds upon a substantial existing literature on gender and employment but departs from it in two significant ways. By paying attention to the situation of young people it attempts to draw attention to particular problems during the process of entering labor markets. It also takes a multi-disciplinary perspective and highlights the social context of work. In the Middle East and North Africa region in general, and in Egypt in particular, studies on transitions to adulthood are scarce and limited to issues of cultural, religious and national identity - often with a focus on young men. Economic studies of unemployment and poverty issues related to women in the labor market focus on women as a whole, without much differentiation by age. ${ }^{1}$ Yet there is good reason to expect the experiences of young women to be considerably different from those of older women, with marriage marking an important point of transition. Recent attention has also been given to the consequences of labor force participation for women. ${ }^{2}$ This study pays greater attention to the motivation for working and factors that influence the demand for work to begin with.

It is important to understand young people's livelihoods because opportunity structures, or lack thereof, at this transitional stage from childhood to adulthood have potentially far-reaching implications in the formation of identity, decision-making abilities (especially important for timing of marriage and childbearing), and status within the household, community and society as a whole. While there is a substantial literature on adolescent reproductive health, on marriage and on the onset of childbearing, this literature largely ignores the role of opportunity structures in determining the timing of marriage and childbearing. Girls may gain skills and experience during this transitional stage through

\footnotetext{
${ }^{1}$ See Karshenas(1994); Assaad (1995,7); Diwan (1996) among others.

${ }^{2}$ See Moghadam $(1993,1998)$ among others.
} 
increased education, especially at the secondary level (Adolescence and Social Change in Egypt, ASCE, 1999), and through the opportunity to work outside the home (see Amin et al., 1997). There is a growing and relevant literature on the contributions of expanding education to the lifecourse development of young people that the current study draws upon.

This chapter provides some relevant background information that informs the conceptual framework for a study of livelihood opportunities for youth in Egypt, especially young women. The objective is to understand how and where opportunities emerge for young people and how they influence and shape identity, behavior and entry into adult roles. Section one defines the concepts used and section two gives a brief background of youth and the labor market in Egypt. Because livelihood opportunities emerge within the labor market and are influenced by changes in labor market conditions, section three explains the structure of the labor market in Egypt; section four discusses the impact of changes in the economy on youth opportunities. Youth choices are influenced by certain institutional factors that are outlined in section five. Section six focuses on young women and the consequences of livelihood opportunities on their well-being. Section seven offers some conclusions.

\section{Concepts AND DeFinitions}

The substantive focus of this study is on young people between the ages of 15-24 years. The United Nations and other important agencies concerned with youth offer all-encompassing definitions and define youth broadly as the transitional period between childhood and adult age, characterized by vigor, enthusiasm and inexperience. It is also defined as a preparatory stage during which young people are prepared for adulthood and active social and economic participation. Such an expansive definition has led to varying age definitions in the literature, ranging anywhere between ages 15 and 34 years. Our choice of the 15-24 age range is justified by our focus on livelihoods and the observation that the majority of young people are expected to experience their transition into adult livelihoods during this time.

Definitions of employment are usually limited to formal regular wage work, which exclude a large segment of young people who are increasingly engaged in informal and casual activity. Definitions of work, on the other hand, include both paid and unpaid activities. Because the focus of the study is on opportunities that allow young people to sustain themselves economically, the term 'livelihoods' is used. Not only is it more reflective of the diverse and complex realities of youth, but it is a larger and more universal concept encompassing more than 'employment' or 'work' (Chambers, 1995:11).

The following section will give a brief background on youth and livelihood opportunities in Egypt.

\section{BACKGROUND}

In 1997, young people between the ages of 15 and 24 constituted a fifth of the total population of Egypt. The cohort is by far the largest entering the labor force. It is also more educated and includes more women than ever before. An important gender differential that characterizes this age group is in the age pattern of marriage. Despite considerable change in 
the mean age at marriage among women in recent decades, they are still five times more likely to be married by age 24 than are men. The legal age of marriage in Egypt is 16 years for women and 18 for men. During the past two decades there has been a trend towards delayed age at marriage among women in Egypt. A study by Rashad and Khadr (1998) shows the proportion of women aged 20-24 who were married by age 20 dropped from 65 percent in 1970 to 41 percent in 1995. A more recent survey on ASCE confirms that 42.6 percent of women aged 20 are married (ASCE, 1997).

The current generation of young people have benefited from increasing level of education. Over 80 percent have completed at least primary schooling, with the largest proportion (about a third) having completed vocational schooling at the secondary level. Despite this impressive development in the overall level of youth education, there are severe gender disparities. One fifth (20 percent) of all young women aged 15-24 have no education, compared to 6 percent of young men in the same age category (ibid.). However, there are signs of progress in this regard as "the proportion of girls who have never attended school dropped from 21 percent among 19 year-olds to 13 percent among the youngest cohort aged 10 in 1997" (Lee, 1999:3).

Those between the ages of 15-24 constitute 22 percent of the total Egyptian labor force. A third work and two-thirds are looking for work. In fact, this age category comprises the largest segment of the unemployed-about two and a half times the unemployment rate for the total labor force (10.8 percent). On average the duration of unemployment ranged from more than a year and a half for the 15 to 19 age category to more than 3 years for youths ages 20-24 (Radwan, 1998:9). Youth unemployment is a more serious problem for females. Recent data show the unemployment rate for young women between the ages of 15 and 24 is three times the unemployment rate of young men of the same age group and more than five times the overall unemployment rate in Egypt (See chapter 3).

For young women between ages 15 and 24 the proportion that is neither working nor attending school exceeds 50 percent. This does not necessarily mean that they sit idle at home. In fact, it is more likely that they are engaged in housework (cleaning, cooking, looking after children or younger siblings) which is invisible in most definitions of work, including the definition used by the ASCE survey. ${ }^{3}$

The majority of working youth in Egypt earn an income from work: half work for cash (54.5 percent) and 11 percent are self-employed. There are significant gender disparities in their work status. Half of male youth are engaged in some income generating activity, with 16 percent in unpaid work. Only 17 percent of young women work (as defined by the ASCE survey) with almost half engaged in unpaid work. Greater gender disparities are found in paid work. 35 percent of male youths are self-employed or work for cash, while only 9 percent of young women earn an income from work (wage work and selfemployment). The discrepancy is larger in self-employment where six times as many young men are self-employed. This gives an indication of the limited availability and restricted

\footnotetext{
${ }^{3}$ The ASCE survey defines work to include gainful employment (worker earns an income) and unpaid work (helping in an income-generating activity for which the worker does not receive payment).
} 
accessibility of credit for young women - an area worth researching further given the rising trend in credit schemes in Egypt.

The cohort of young people of interest to this study is best viewed as a birth cohort that has gone through a boom and a bust economy. They were born between 1975 and 1984, when the Egyptian economy was growing at an unprecedented rate of 8 percent per annum. It was a period marked by high oil revenues, steady flows of resources from the Suez Canal and tourism in addition to workers' remittances. Although the leading employment sectors-agriculture and public services-were reaching saturation, and growth was mostly capitalintensive, labor demand in the Gulf countries absorbed the excess labor. During their childhood and adolescence, the economy turned less favorable. External debt reached unsustainable heights and the fiscal deficit reached a critical level. The boom effect of the increase in oil prices eroded. The Gulf war resulted in large numbers of returning migrants. Domestically, growth slowed down tremendously (Radwan, 1998).

Egypt started its Economic Reform and Structural Adjustment Program (ERSAP) in 1991 with the support of the International Monetary Fund and the World Bank. The first phase of ERSAP addressed macro-economic stabilization policies to reduce the large budget and balance of payments deficits. In January 1996 efforts were intensified to include structural reforms in the economy.

Many agree that Egypt's Economic Reform and Structural Adjustment Program was successful in its stabilization objectives. The budget deficit was reduced to a sustainable level (from 15 percent of GDP in 1991 to 4 percent in 1992 and reaching less than 1 percent in 1997), and inflation dropped from 21 percent in 1991 to 6 percent in 1997 . While it is still too early to determine success, adjustment policies have had a substantial impact on the Egyptian economy. Local currency was devalued and exchange rates unified; government controls on prices and quantitative import restrictions were dismantled. Tariffs and subsidies were reduced. Interest rates were liberalized and credit restricted, which succeeded in raising the interest rate from negative values to high positive values (Karshenas, 1994:27). These fiscal and monetary 'successes' were achieved at the cost of growth. The growth of the economy dropped by half from an annual average growth rate of 3 percent (in Real GDP) during 1987-1990 to an annual rate of 1.4 during 1991-1994. The share of investment and savings also declined by 21 and 27 percent respectively between the two periods. Growth picked up during 1996 and 1997. GDP growth rate reached 5.2 percent in 1997. Although still low, savings increased reaching 12.8 percent of GDP in 1997-- the highest level reached since 1986. Domestic investment increased slightly over the decade but still remains low at 18 percent of GDP.

Despite these positive signs, serious concerns remain regarding the social implications of economic reforms, especially in terms of livelihood opportunities and poverty. Estimates of unemployment and poverty in Egypt show a rising trend since the late 1980s. While some attribute unemployment and increasing poverty to the ERSAP, it is not clear whether the situation would have been otherwise had Egypt not embarked on these reforms. Proponents of ERSAP believe that Egypt's adoption of the economic reform program saved the economy from a major economic crisis. While economic growth is 
necessary, it is not sufficient for the success of reforms. The nature and structure of the labor market and the mobility and flexibility of labor are also critical in determining the success of economic reforms.

\section{STRUCTURE OF THE LABOR MARKET}

Two main structural aspects of the Egyptian labor market should be considered. At one level there is the public (government and public enterprises) versus the private sector. Whereas the public sector offers opportunities for formal wage employment, the private sector includes both formal and informal work with a plethora of activities, conditions and remuneration methods. Thus at a second level, there is a distinction between formal and informal work. Within these two levels, the market may also be classified in terms of economic activity whereby livelihood opportunities arise within agriculture, industry or services. Within the various sectors and economic activities, a fourth level can be distinguished whereby specific occupations emerge.

Livelihood opportunities in the public sector are those activities under the control and direction of the state. They include jobs in government agencies and public sector enterprises where the state owns all the resources. The government has been the most important source of livelihood opportunities in Egypt especially for graduates. In 1995 it provided 46 percent of total wage work in the economy. An employment guarantee program established in the early 1960s boosted the demand for education, and expanded the public sector (government and public enterprises) significantly. Between 1966 and 1983 the number of graduates eligible for the scheme increased from 39,000 in 1966 to 318,000 in 1983 - an annual growth rate of about 12 percent. The share of graduates in the annual increment to the labor force grew more than four-fold, from 17 percent in 1963/64 to 77 percent in 1983. Between 1981 and 1984, government employment grew at a rate of 8.4 percent. Due to severe budgetary pressures, the growth rate declined to an annual rate of 4 percent between 1984 and 1992 (Assaad, 1995:4). Subsequently, with the adoption of the economic recovery program, the growth of government employment dropped further to an annual rate of 1.8 percent between 1992 and 1995 (Assaad, 1997:59).

Similarly, the public enterprise sector grew significantly faster than overall employment in the late 1970s and early 1980s. However, towards the latter part of the 1980s and early 1990s it declined significantly, such that between 1984 and 1992 the growth rate was merely 0.8 percent per annum. In 1995, the share of public enterprises in total wage employment was 16 percent. With the privatization of public enterprises the opportunities offered by this sector diminished further (Assaad, 1995:4). The public sector, broadly defined, constitutes the largest share of employment (62 percent). Although many of today's youth aspire to a job in the government and public sector (due to job security and benefits), with the retrenchment objectives of the Economic Recovery Program, the public sector will offer fewer and fewer opportunities for youth. In fact it will most likely be shedding labor which will need to find opportunities in other sectors of the economy.

The private sector involves activities that are owned and directed by nongovernmental economic units such as households or firms. In 1995, private wage work in 
Egypt constituted 18 percent of the total wage employment, mostly accounted for by private sector agriculture. Agriculture is the primary source of private employment. The nonagriculture private formal sector (with at least ten workers) has grown quite rapidly but its contribution to total employment is relatively low, as most investments have been relatively more capital intensive than labor intensive.

In Egypt, the informal sector has been growing substantially during the past decade, absorbing the increasing numbers of new entrants into the labor market, especially new graduates waiting for a government job. Estimates of its size vary due to the different definitions and estimation methods used by different authors. This sector, which includes small establishments (less than 10 employees) and employment outside establishments has shown increasing importance in livelihood opportunities since the early 1980s. According to the 1995 Labor Force Sample Survey (LFSS) it constituted 18 percent of total wage employment. The Egypt Human Development Report 1996 stated that the informal sector grew from 22 to 24 percent between 1977 and 1992. Informal employment opportunities in urban areas grew to 1.9 million, constituting around 60 percent of the total workforce in the private sector. If establishments employing less than five workers are considered as part of the informal economy, then the total number of people operating within the informal economy was estimated to be around 3 million people in the early 1990s (UNDP, 1996).

Assaad argues that with the small size of the formal private sector and the limited availability of jobs in the public sector, the informal sector has become "by default the leading sector of labor absorption in the Egyptian economy" (Assaad, 1997:61). Handoussa and Potter further argue that the informal sector in Egypt is "resilient, dynamic and successful enough to become an engine of growth" because not only does it absorb youth labor, but it also offers market skills such as entrepreneurship and individualism which may empower young people to participate more effectively and also promote sound economic progress. (Handoussa and Potter, 1992)

\section{ECONOMIC REFORM AND YOUTH OPPORTUNITIES}

Opportunity structures are influenced and shaped by conditions in the labor market and the economy. The process of change in the economy creates opportunities in some sectors while destroying them in others. As mentioned earlier, Egypt embarked on economic reforms early in 1990 and started the Economic Reform and Structural Adjustment Program in 1991.

Such reforms usually consist of two major components: Stabilization and Structural Adjustment. Stabilization entails measures to reduce the payment deficit and curb aggregate demand. Stabilization measures are usually not optional and are adopted when a country's payment deficit reaches a crisis point. Structural adjustment on the other hand involves the reallocation of resources between the different sectors of the economy. Structural Adjustment Programs (SAPs) have various dimensions including a shift in the factors of production (capital and labor) from the production of non-traded goods (e.g. services) to tradables, especially export production. The exchange rate is usually the mechanism used to 
drive this structural shift. SAPs also involve public sector retrenchment and an expansion of the private sector.

The impact of SAPs on livelihood opportunities depends on a number of issues: the desirability and feasibility of certain livelihood characteristics and options; the nature of the labor market; the policies necessary to achieve adjustment, the sequence of their implementation, and their overall impact on economic growth. The impact of stabilization policies on livelihood opportunities is almost always negative in the short run. Cuts in public spending and freezing of public sector hiring have a direct negative effect, whereas increases in the interest rate which lead to reductions in investment and the slowing down of economic growth results in a gradual erosion of livelihood opportunities. Adjustment on the other hand may increase employment in some sectors and reduce it in others. What is important for the success of these SAPs is a positive net effect on overall employment.

The effects of SAPs on living standards of various groups can be complex. In general, economic conditions impact variably on women's economic activities and employment patterns. Times of economic growth and high wages for men could result in limited female participation or 'female domesticity' (as in the case of most of the Gulf countries in the 1970s). Periods of adverse economic conditions may force women to seek livelihood opportunities (Moghadam, 1998:7). Most critics of SAPs argue that the burden of adjustment almost always falls on women. That is because women tend to be concentrated in the nontradable sector and are less intersectorally mobile. A shift from nontradables (i.e. the public sector and service activities) to the tradable sector would result in a decline in the relative price of women's labor but the absolute losses in income will exceed the price decline. Hence, Structural Adjustment would result in a decrease in the returns to women's labor (Collier, 1994:301-302).

In Egypt, women are mostly concentrated in the public sector and in nontradable activities such as services. With Egypt's economic reform program, women are increasingly perceived to be more vulnerable than men and more likely to be laid off in the public sector and less likely to be hired by the private sector (Moghadam, 1998:7). Information on the impact of the ERSAP on the various groups is either hypothetical or based on a small number of case studies. It is not known for sure whether women-young or old, have borne the brunt of economic reforms in Egypt. It is important to understand the social context which influences the status of women and their mobility in the labor market.

\section{THE SOCIAL CONTEXT OF WORK}

Women's involvement in the labor market in Egypt has historically been limited to low levels of engagement in the formal sector. Women's economic contributions were traditionally confined to the domestic sphere although they made considerable contributions on farms and in agricultural processing. Several public policy interventions, including the increasing educational opportunities for women and the large scale induction of women into public enterprise jobs, has changed the role of women in labor during the last several decades. These forces of tradition and change continue to assert their influence on the labor market and influence opportunity structures in the labor market and at the household and 
community level. Some reports from the field lead us to hypothesize that households are responding to increasing economic hardship by allowing young women to seek paid work outside the household (Al-Bassusi, 1997 personal communication). However, supply and demand in the labor market respond to various influences. While economic changes may be removing cultural constraints and increasing the supply of female labor, demand on the part of employers remains low. While employers are also influenced by cultural norms, they are further constrained by the policy environment. Increasingly over the past few years, policy makers in Egypt have been trying to boost investment, both domestic and foreign, to encourage the private sector to grow and offer greater employment opportunities. Protective legislation that in theory works to the advantage of women restricts employers and raises the cost of hiring women, and hence in reality works against women. Such protective legislation as embodied in the labor code is currently being reviewed in an attempt to remove some of the constraints on the growth of the private sector while maintaining the rights of workers.

Change in the economy, in cultural norms or in policy may generate contradictory outcomes. While it may offer greater livelihood opportunities and more autonomy and resource control for women in the household, it may also entail greater inequality, subordination and exploitation for women in the market (Safa, 1981; Standing, G. 1989). It is difficult to assess the net effects of these changes in the economy as to whether they have on balance been positive or negative, but it is clear that they have initiated an elaborate process of change in household calculus on the matter of women's roles. The following section explores the link between livelihood opportunities in the market and the well-being of young women.

\section{YOUNG WOMEN AND LIVELIHOOD OPPORTUNITIES}

Work opportunities allow young women to experience a transitional period as they move from childhood and before they embark on the responsibilities of adult life. To the extent that work enhances choices for these women and allows them more agency in terms of deciding on the timing of assumption of other adult roles such as marriage and childbearing, it may be argued that such expansion of opportunities is potentially empowering for young women. Opportunities at this stage may also contribute to their social, economic and psychological development and well-being. Evidence from research suggests that the ability to take greater control of one's own life and decision making skills are acquired early in life through experiences at a young age (Nawar et al., 1995:153-4).

The concept of well-being includes numerous elements such as freedom, autonomy, and empowerment. Freedom of choice, many would agree, is essential to well-being, both instrumentally, as a means for achieving other ends, and intrinsically. Freedom may also be defined as the ability to make choices without external restrictions or interference (Anand, 1994:77). Like freedom, autonomy also forms an important part of well-being. Autonomy is defined as "personal freedom" or "freedom of the will" (Pearsall and Trumble, 1995:93). It is the ability to think and act independently in achieving one's goals or intentions within given economic, social and cultural structures (Nawar et al., 1995:151). While well-being is sought in all societies, the value given personal freedom and autonomy differs across societies. Western cultures place a high value on these notions while non-Western societies 
usually give social interdependence greater value, with a "tacit recognition that the ability to carry out one's intentions is desirable, though it may be expressed in terms of 'influence' as opposed to "autonomy"' (ibid:152-3).

Some view livelihood opportunities as an empowering experience that may change women's perceptions of self-worth and well-being, provides other sources of social support, and has the potential to reduce women's dependence on others (Mahmud and Johnston, 1994:153). Some studies show that independent earnings by poor women have an effect on traditional gender relations within the household and enhance women's participation in decision-making. Some of these studies maintain that outside earnings enhance women's capabilities in dealing with threats and crises and offers them higher self-esteem and higher status within the family (see, for example Mahmud and Johnston, 1994). In Egypt, ethnographic research on some communities in Cairo also suggests that income-earning women enjoy an elevated status within the family in the form of privileged treatment and greater say in financial matters (see Hoodfar, 1988 and Ibrahim, 1982, cited in Nawar et al., 1995:160).

The relationship between livelihood opportunities and greater autonomy in decisionmaking is not automatic. It dependents on several factors such as type, nature, duration and continuity of employment, in addition to institutional structures that govern the value of women's labor and the conditions under which women engage in economic activity (Mahmud and Johnston, 1994:153). The 1995 Egypt Demographic and Health Survey (EDHS) states that women who are engaged in paid work also have limited financial autonomy over their earnings. Two in three gave all of their earnings to the family. Only 14 percent of women owned any assets that they could sell without permission (EDHS, 1995). The report further states that, while in general Egyptian women appear to have limited autonomy in household decision-making, women in wage work are twice as likely as women in unpaid work to participate in decision-making (EDHS, 1995:192).

\section{CONCLUSION}

This chapter offers a conceptual framework for the study of livelihood opportunities and consequences for youth, with particular attention to young women. It places youth within an economic and socio-cultural setting and links notions of well-being with opportunities for paid work. With new patterns of production and new opportunities at a global level, gender relations in the household and market place will necessarily take new forms.

A few major points emerge and are worth emphasizing. First, livelihood opportunities may be a pathway through which young women can delay marriage and childbearing and acquire necessary skills. Secondly, work experiences for young women are not simply positive or negative, but involve a complex process of deliberation between cultural norms and economic incentives through which there are benefits and costs. There is a crucial role for policy in reducing the costs and increasing the benefits, but legislation must be designed carefully, considering both the needs of young women and the requirements of the labor market. 


\title{
Chapter Two
}

\section{The Policy Context}

\author{
Safaa El-Tayeb El-Kogali
}

\section{The State shall guarantee the protection of motherhood and childhood, take care of children and youth and provide the suitable conditions for the development of their talents}

(Article 10, emphasis added).

Work is a right, a duty and an honor ensured by the State

(Article 13).

(Constitution of the Arab Republic of Egypt, 1980)

\section{INTRODUCTION}

The objective of this chapter is to review some of the main policies and laws in Egypt that shape opportunity structures for young people in the labor market. As with the previous chapter, the situation of young women will be given particular attention. The first section sets the context and gives a brief background. Section two reviews some of the policies that affect youth opportunities in terms of quantity. Section three addresses issues of quality in terms of work relations and conditions. Section four focuses on women and section five concludes.

\section{BACKGROUND}

Before embarking on an assessment of the laws and policies which affect opportunities for youth, it is important to understand the context within which these policies are formulated and the transitions the state in Egypt has passed through during the past five decades. To understand these transitions, three periods in Egypt's contemporary economic history are distinguished: the 'pre-reform' era which covers the 1950s and 1960s, the 'initialreform' period which covers the 1970s and 1980s and the 'reform' decade which covers the 1990s. Policies formulated during these three periods have shaped the structure of opportunities in the economy for young people today. 


\section{The Pre-reform Era}

This is the period of Nasser's Egypt where the state followed a socialist doctrine with a centrally planned economy and a comprehensive welfare system. In common with many developing countries at that time, Egypt followed an import-substitution, closed-door policy, and concentrated on capital-intensive industrialization. To replace the large number of expatriate technicians who left the country after the Suez Crisis in 1956, and as part of a major public employment drive in the early 1960s, the Graduate Employment Guarantee Scheme was established. It guaranteed employment for university graduates and later also for vocational secondary school and technical institute graduates. In 1964 the scheme was formalized in Law 14. When the scheme was fully implemented in 1963/64 graduates constituted about 17 percent of the annual increment to the labor force. Two decades later, they formed 77 percent of that increment.

While the scheme may have succeeded in achieving its objectives, it had far-reaching consequences that influenced the education system and continued to influence the structure of opportunities for youth 25 years later. An increase in demand for secondary and higher education can be attributed to the assurance of jobs provided by the employment scheme. Moreover, the scheme distorted labor allocation in the market away from the private sector given that benefits and job security in the public sector were incomparable to those of private sector jobs. Although the scheme may have boosted female education and labor force participation, the guarantees associated with the public sector led to a concentration of women in government jobs or to what some refer to as the 'feminization' of public sector jobs (Assaad, 1995:20).

\section{The 'Initial Reform' Period}

The initial reform period began with President Sadat's Open Door policy in the early 1970s. It marks a period of transition for the state and economy in Egypt. While policies were introduced to liberalize trade and encourage private investment, existing legislation which was based on socialist principles was not modified sufficiently resulting in gaps and contradictions in the various laws (Handoussa, 1989). The public sector continued to grow, attracting the young educated new entrants. In 1973, the Graduate Guarantee scheme was made permanent in Law 85. Declining oil revenues put pressure on the fiscal budget and the burden of the employment guarantee scheme became unsustainable. Instead of abolishing the program, the government opted for a more gradual approach. The waiting period for government appointment was extended in the hope that some graduates would seek opportunities elsewhere. The extended waiting period created a queue for government jobs with appointments made on the basis of time spent in the queue. The 1983 cohort of university graduates and 1982 cohort of vocational secondary and technical institute graduates were the last appointments as of 1995. Although appointments were subsequently stopped, the scheme was not abolished.

The formal abolish of the guarantee program is assumed to carry high political costs and has never been implemented. It is argued that since in practice the program is not in operation, there is no benefit in formally abolishing it, instead the government should concentrate its efforts on finding alternative employment for youth. A counter argument is 
that as long as the scheme is not formally abolished, graduating youths will aspire to a public sector job which will in turn affect their labor allocation decisions (Assaad, 1995:20).

Although this period may have marked the initial reform process, the inconsistencies in policies and the piecemeal approach has only served to make the situation worse and to aggravate the social cost of reform to be borne by the Egyptian people in the following decade (Handoussa, 1994:21).

\section{The Reform Decade}

By the end of the 1980s, the Egyptian economy was in crisis: the budget deficit had reached unsustainable levels, growth had slumped, and unemployment had soared. Handoussa argues that the "legacy of four decades of heavy state involvement in the Egyptian economy has been more negative than positive, culminating in a set of unsustainable imbalances" (Handoussa, 1994:21). In 1991, the government adopted the Economic Recovery and Structural Adjustment Program (ERSAP) in an attempt to stabilize the economy and restructure the market for a more efficient allocation of resources and more effective operation of the market mechanism. The structural adjustment component of the ERSAP was the force shaping opportunities for youth in the labor market during the 1990s. The following section will explore the impact of some of these reforms on youth opportunities.

\section{Privatization And Investment Policies}

The Egyptian constitution gives primary responsibility to the public sector as "the vanguard of progress in all spheres" and to "assume the main responsibility in the development plan" (Article 30). The private sector on the other hand is to be organized "within the framework of the development plan"(Article 32). The development plan since the early 90s, has been the ERSAP, with the objective of reversing the public/private balance - i.e. developing the private sector to assume a primary role in the market and limiting the role of the public sector. Privatization policies and investment laws were enacted toward achieving this objective.

\section{Privatization}

Privatization of state enterprises was first introduced in the mid-1970s as part of President Sadat's reform policies, but due to widespread public opposition, no concrete steps were taken. While joint ventures were initiated and foreign leasing increased, only two factories were privatized during the 16 years between 1974 and 1990 (Posusney, 1995:67). It was not until the adoption of the ERSAP in 1991 that privatization emerged high on the political agenda. Law No. 203 of 1991 provided the legal framework for the privatization of most of Egypt's public sector enterprises. In addition to the 314 state-owned enterprises that were earmarked for privatization in Law 203, 23 joint venture banks were added to the list in 1994.

To avoid an eruption of widespread public opposition, the government adopted a gradual approach targeting specific enterprises one by one. During the first four years, the government was criticized by donors and lending institutions for the slow pace of its 
privatization, efforts. In 1996 the pace picked up and assets worth over $\$ 800$ million were privatized, in addition to $\$ 1$ billion of local governorates' assets, joint venture companies and unutilized fixed assets. By 1996, 83 percent of state-owned companies earmarked for privatization were at least partially privatized, and in June 1998, 84 additional companies were transferred to private ownership (El-Kogali, 1997).

While law 203 formalized privatization efforts, it maintained the protection of workers' rights as stated in the labor code (guarantees against arbitrary firing and mass layoffs and the continuation of pensions, health and accident insurance). However, increasingly there is pressure on the government to revise the labor code to ease these restrictions. That is not to say that violations of the labor code do not exist; for years, private businesses have been finding ways around labor restrictions. The government may have been able to turn a blind eye to these violations in the past as they were small private firms. With the transfer of a large number of state enterprises to private ownership, the issue has taken on a larger scale and more national attention which puts pressure on the government to address labor concerns (Posusney, 1995:73). A new labor law has been drafted and is under negotiation. Section three will discuss the labor code in greater detail.

While public sector workers continue to be protected by the labor code, it is the young new entrants into the labor market who have suffered most from privatization. After decades of the employment guarantee scheme, young graduates expected a government job almost as a right. Privatization policies reduced the chances for public employment, resulting in increased unemployment and underemployment. Since the guarantee scheme was not formally abolished, young graduates, especially women, continued to aspire to a government job. Those who join the private sector do so until their turn in the queue for a government job comes up. Increasingly, young men are giving up on the public sector and are moving towards private employment, however, given access barriers for women in the private sector, most female graduates either remain in the queue for a government job or exit the labor force all together. Privatization of public enterprises was not matched by growth in private investments, further narrowing opportunities for young people in the labor market. What follows is a discussion of the policy efforts in expanding the private sector.

\section{Investment Laws}

Livelihood opportunities in the labor market are essentially a function of investments in the economy. It is these investments that create jobs for the young new entrants into the labor market. With the end of the graduate scheme and the shrinking of the public sector, the private sector is the future for youth livelihood opportunities. Over the past fifty years numerous laws that affect private investment have been passed. These include investment laws, company laws, commercial laws, tax laws, industrial laws, ownership and registration laws, in addition to special laws directed to specific sectors or development areas. In addition to regulation, these laws provide incentives for investment. To go through all these laws is beyond the scope of this paper. ${ }^{4}$ Focus will be on investment laws since they have the most direct impact on creating work opportunities in the economy.

\footnotetext{
${ }^{4}$ See Nathan Associates Inc. Development Economic Policy Reform Analysis Project, 1997 for a review of some of these laws, although the emphasis of their report is on foreign direct investment and not private investment in general. Also see Handoussa, 1989.
} 
The government has progressively opened up the economy to private investment since the mid-1970s, starting with Law 43 of 1974. The law opened all fields of economic activity (with the exception of petroleum exploration and production) to investors, including foreign and Arab investors. It offered incentives in the form of income tax holidays and customs exemptions on capital goods for some projects. In 1977, Law 43 was revised; among other changes, it allowed private domestic investors the same terms as foreign investors as long as they invested in foreign currency. Between 1974 and 1988, Law 43 had attracted 850 new inland investment projects that were in operation, creating 147,000 jobs (Handoussa, 1989). These projects accounted for 47 percent of gross fixed private investment outside agriculture and petroleum. Nevertheless, Law 43 was increasingly recognized as insufficient to cover private investment in Egypt (UNCTAD, 1999).

In 1989 Law 230 replaced Law 43 as The Investment Law, providing greater incentives for private investment, especially to foreign investors. The new Investment Law 230 and the Companies Law 159 of 1981 became the two basic laws governing private investment in Egypt. Between 1989 and 1997, 3,733 new inland projects were approved, expected to create 470 thousand jobs. By 1997, the Free Zones areas attracted 819 projects of which 380 were in operation (ibid.). Other laws and decrees were issued that had a direct or indirect impact on private investment. It was estimated that about 20 laws or decrees with statutory effect governed domestic and foreign investment in Egypt. In addition to the Investment Law and the Companies Law, these included The Commercial Register Law, the Income Tax Law, the Industrial Licensing Law, The New Urban Communities Law, The Industrial Shops Law, and several others (Nathan Associates, Inc., 1997).

The legal framework for investment became highly complex and there was a need to simplify it into one unified law. After three years of preparation, Law 8 was enacted in 1997 as a unified law replacing the many laws governing private investment and offering greater incentives and guarantees. This is the law that governs private investment in Egypt today. While some (e.g. UNCTAD, 1999) praise the new law for unifying the previous profusion of investment legislation, others (e.g. Nathan Associates Inc., 1997) argue that it does not mark any improvement on previous laws. Opponents mainly refer to ambiguities and gaps in the new law which gives greater discretion to the implementing body. The legal framework establishes the environment for private investment. If it is too complex or ambiguous, it may discourage private investment, especially foreign investment.

\section{The Special Zones}

As part of its efforts to attract private investment, Egypt established special zones. Export Processing Zones or EPZs have been established in Egypt under Law No. 43 of 1974 entitled The system on the Investment of Arab and Foreign Funds and Free Zones, with the objective of creating jobs and increasing employment opportunities through export promotion. When the Investment Law No. 230 of 1989 replaced Law No. 43 of 1974, Chapter 3 of Law No. 230 was dedicated to Investment System in the Free Zones. It consisted of 17 articles giving details of rules and regulations on the administration and management of investment projects in the Free Zones (World Bank, 1997). Egypt's free 
zones are geographically located in strategic positions within the region and offer substantial benefits and simplified procedures. Due to the special incentives offered, free zones have been highly successful in Latin America and Southeast Asia in attracting investment projects, especially the transnational companies (TNCs). EPZs offered work opportunities for a large number of young people in these regions, especially young women. In Egypt, although free trade zones enjoy special incentives, they have been less successful in attracting investment projects (UNCTAD 1999).

New Urban Communities have been created (Law No. 59 of 1979) to attract population away from the existing greater urban centers by establishing industrial/residential developments, creating job opportunities and attracting residents. These communities offered high incentives for investors in the form of subsidized land with modern infrastructure and up to 10 years tax breaks for all development (World Bank, 1997). The first and second generation of eight new industrial cities established in the desert (Tenth Ramadan, Sixth October, Borg Al Arab, Sadat City, Amerya, Salheya, Badr and Obour) have been successful in attracting investment. In 1997, the eight industrial cities hosted a cumulative 1,093 projects (approved) valued at LE 28 billion and employment of 187,557. New communities have also been recently launched in the Southern Valley (UNCTAD 1999).

Industrial zones, which are located adjacent to existing urban areas, have also attracted a large number of investment projects. Recently 5 zones were developed in Upper Egypt, adjacent to the existing cities of Assiut, Minia and Sohag with a total of 1,257 approved investment projects estimated at 1.7 million Egyptian Pounds. These projects are expected to create about 62 thousand jobs with an average of LE 27,612 of capital cost per job (ibid.).

The development of these zones has contributed to the regional distribution of employment opportunities for young people away from the traditional urban centers. While the new zones may offer new locations of opportunity, they raise issues of mobility, especially for young women, given the distance and time required for travelling from urban centers or villages. In Southeast Asia, it is acceptable for young women to live in housing compounds set up in such zones, but in Egypt, social and cultural constraints do not allow young unmarried women to live alone or in compounds away from home. Hence, while these special zones may attract young people, unless investments in transportation are made, young women may be constrained from these jobs.

The nature of investment projects is important in determining opportunities for work in at least two ways: First, the extent to which investments are capital- or labor-intensive. There is criticism that most investment projects approved have been capital-intensive and do not create sufficient jobs to absorb the large pool of young people seeking employment. Secondly, the sector of investment and the kind of jobs created determines the gender base of opportunities, especially in a market that is highly segmented along gender lines. (The following chapter will show the extent to which investment projects have been able to absorb young men and women.) 
Overall, the impact of privatization efforts in the public sector succeeded in changing the public/private share of Gross Domestic Product (GDP) in Egypt. In 1990 the share of public investment in GDP was more than double the share of private investment. Five years later, in 1995, the share of private investment became double that of public investment in GDP. This is due to the significant decline in public investment and not to an increase in private investment. The share of private investment was more or less invariant during the five years at an average of 10 percent, despite the many incentives offered and investment projects that were approved (El-Kogali, 1997a). Low private sector investment may be due to a number of factors. A major determinant of private sector development is investors' perceptions, which are in turn a function of the investment environment. In addition to investment legislation and incentives, the social and political stability of the country, the cost and productivity of labor and labor codes, all contribute to the investment environment. The next section will address the labor code and discuss how it may have contributed to the slow private sector development in Egypt.

\section{LABOR LAWS}

While investment laws create work opportunities for youth, labor laws influence the conditions and quality of work. However, labor laws may also indirectly affect job opportunities. There is evidence that stringent labor laws deter employers from hiring and lead them to exploitative practices and poor work relations with workers (see the next section on women). Law 137 of 1981 is the principal legislation governing individual employment relations in Egypt. The law applies to all workers with the exception of civil servants in central administrative organs of the state and local government units, household service workers, and family workers. Law 137 governs, in great detail, the nature and structure of individual work relations including contracts, wages, benefits and employee responsibilities, in addition to sections covering the employment of minors (Section two, articles 143 to 150) and employment of women (Section three, articles 151 to 159).

The labor law offers extensive protection to employees, guarding them against dismissal except in cases of committing a "serious mistake" (Section 4, Article 61). Nine cases are considered "serious mistakes" including (i) wrong identity, (ii) action which results in large material losses to the employer, (iii) absence without a permissible cause for more than twenty days in a year or more than ten consecutive days, (iv) failure to follow safety regulations of the entity, (v) failure to carry out terms of reference as stated in the contract, (vi) failure to respect confidentiality of work information, in addition to (vii) being indicted for a criminal offence, (viii) or found to be under the influence of alcohol or drugs during work hours, or (ix) a physical attack on the employer, manager or any work supervisors during work hours (ibid.). Even if a worker should commit any of the above 'serious mistakes' the employer could not dismiss him/her immediately, but must go through a committee which takes the final decision on the case. Eight articles of section five in the labor code focus on the details of the process.

While the objective of job security legislation is to protect employees against the exploitation of employers, it has resulted in unintended negative consequences. In principle the labor code applies to both the public and private sectors. However, there is strong evidence that the majority of private sector employers evade the labor code and have 
developed ways around its restrictions, for example, making workers sign an undated resignation letter when they first join a firm. This has created a gap between the two sectors whereby job security became attached to public sector jobs. Although the private sector offers higher wages, most people appear to value job security over pay, resulting in a constant demand for public sector jobs. Public sector employees hold on to their jobs and compensate for the low wages by taking up multiple jobs. The gap between the public and private sector has affected labor allocation decisions of the young new entrants into the labor the market whereby the majority, especially women, opt to wait in the queue for a government job rather than seek employment in the private sector. Moreover, within Egypt's context of economic reform and structural adjustment, job security legislation constrained labor mobility between sectors and thereby substantially increased the burden of adjustment, especially for private sector employees.

In an attempt to remove structural rigidities within the labor market, the government of Egypt drafted a new labor law to replace Law 137. The draft law contains 270 articles covering all aspects of work in the economy. While much of the current law remains the same there are major changes, especially with regard to work relations. Employers are given more flexibility in the hiring and firing of workers. Article 14 of the draft labor law allows employers to hire workers independently of the labor office. With the current law, employers must go through a government agency to hire workers. While this has been the law, in practice, most private firms hired workers freely. The proposed new law merely legitimizes the on-going practice.

The proposed labor law also gives employers the right to fire employees without having to go through the long process outlined in the current law. Article 69 states "it is possible to fire a worker if he/she does not carry out one of his/her core duties, especially in the following cases [emphasis added]" and nine cases are listed. While the nine cases are similar to those in the current law, the wording of the article differs substantially. In the current law, firing of workers is not allowed except if the worker commits a "serious mistake" and the nine cases are listed to define a serious mistake. The proposed new law gives employers greater discretion in firing workers and the nine cases listed are not exclusive. Article 110 of the proposed new law further allows employers to terminate a worker's contract, if the contract does not have a fixed-term, on grounds of a "legitimate and sufficient reason which relates to the worker not fulfilling one of his/her core responsibilities or qualifications". What constitutes a legitimate or sufficient reason is not clearly defined.

To balance this big step in favor of employers, the proposed new labor law gives workers the right to strike. Section five contains five articles on strikes. Article 193 allows workers to exercise the right to strike through their union organizations in defense of their interests and within the regulations of the law. Although permitted, the right to strike is restricted by several conditions. It requires a two-thirds acceptance by the Workers Union Board and a written notice of the intention to strike must be sent to the employer through registered mail at least 15 days in advance, and must contain an explanation of the reasons leading to this decision (Article 194). Strikes are prohibited during arbitration and/or mediation or for the purpose of modifying an active collective agreement (Article 195). Strikes are also prohibited in establishments that cater for "vital public services" where the 
interruption of these services would lead to disruption of daily activity for the majority of citizens (Article 196). These establishments are not determined in the law; they are to be identified by a decree from the Prime Minister. Another major restriction on strikes is stipulated in Article 197 whereby "a worker's contract is suspended and not terminated during a strike except in the case of a "serious mistake" committed by the worker during a strike".

Although the draft law was put together through negotiations between the government, employers and employees, it is still widely debated. The core of the debate revolves around job security regulation. It is argued that the proposed new labor law substantially increases employer discretion on work relations, and the right to strike aimed at protecting workers is constrained by stringent conditions. Moreover, the proposed law contains many ambiguities that may be exploited by employers against employees and may lead to the destabilization of work relations (See discussion papers on the proposed new labor law by the Democratic Development Group, 1998). In general, the debate appears to be on the extent of flexibility the proposed new law offers. While the current labor law had been criticized for its rigid regulation of work relations, the proposed law is regarded as having gone too far the other way in offering too much flexibility to employers. Should the obstacle to private sector development in the past have been the rigidities in the labor code, then the proposed new law presents a step forward in removing these rigidities and contributing to a better investment environment.

The proposed new labor law was first drafted in December 1994 and revised in January 1996, but to date, it has not been ratified by parliament. As with privatization, the government may be delaying action on the new law to avoid protest from workers. However, the government can not postpone the decision too much longer as there is growing pressure from the business community and international donors to adopt the new law. The debate on job security regulation is an old one and the literature is full of arguments for and against it. What is important is not the amount of regulation or flexibility but the coherence of policies that would set a balance and would lead to growth in the economy and the development of its workforce.

\section{Women ANd Policies}

Legislation is among the most important factors that influence the position of women in the labor market and must be appropriate for the social and economic conditions of the society concerned (Hoodfar, 1997:108)

In theory, women are guaranteed equal access to the labor market. Article 11 of the Constitution of Egypt states that "[ $[$ ] $h e$ State shall guarantee the proper coordination between the duties of woman towards the family and her work in the society, considering her equal with man in the fields of political, social, cultural and economic life without violation of the rules of Islamic jurisprudence" [emphasis added]. Towards achieving this goal, the labor code contains an additional section focusing solely on the employment of women: articles 
151 to 159 of the Labor Law 137 in addition to Decrees number 22 and 23 of 1982, offering special benefits and work conditions.

Women are prohibited from working night shifts between 8 p.m. and 7 a.m. (Article 152). Exceptions are determined by Decree number 23 of 1982 . Women are also prohibited to work in certain jobs that may be harmful to their health or morals (Article 153). A list of these jobs is provided in Decree number 22 of 1982. After six months of employment with an employer, a woman is entitled to paid maternity leave of fifty days and may use this entitlement up to three times during her service to this employer; women are prohibited from employment during the first forty days after delivery (Article 154). During the first 18 months after delivery, a nursing worker is entitled to two additional breaks during working hours no less than half an hour, and she may combine these two breaks into one. These additional breaks are considered part of working hours and may not result in a reduction of her wage (Article 155). Moreover, women who work in establishments with fifty or more female employees are entitled to unpaid leave up to one year to look after their children and may use this entitlement up to three times during their service (Article 156). Firms that employ a hundred women or more, as well as firms who are in the same neighborhood with less than one hundred female employees, are required to establish a nursery for the children of their employees (Article 158).

While the intention of such legislation is to encourage women to participate in the labor market, not much was done to change domestic gender structures since women were expected to coordinate their work at home and in the market (Hoodfar, 1997:106). This resulted in a gender-segmented labor market. Further, increased protection of women in the labor market resulted in discouraging employers from hiring women. Job types and working hours for women are limited and the extensive entitlements add extra costs to employers. Therefore, employers would prefer to hire men, further reinforcing gender segregation in the market. There is evidence that private firms that hire women developed ways to evade these restrictions. For example, large firms would fall short of hiring one hundred women at any one time to avoid setting up a nursery. Thus, legislation aimed at enhancing the status of women in the labor market has in practice worsened their position.

There have been minor changes in the proposed new labor law with regard to women. The duration of maternity leave was extended from fifty to ninety days, required time in service was increased from six to ten months and the entitlement to this option was reduced from three times to twice during the employee's service (Article 91 of the proposed labor law). Unpaid leave for women in firms with fifty or more female employees has been extended to a maximum of two years to allow for child care (Article 94). There are arguments that the articles pertaining to women's work in the proposed new law conflict with the Child Law no. 12 of 1996. For example, Article 91 of the proposed labor law that limits entitlement to maternity leave twice for the total duration of a woman's service, conflicts with Article 70 of the Child Law that stipulates a woman's entitlement to maternity leave is three times for the total duration of her service (Democratic Development Group, 1998:27). Similarly, Article 92 of the proposed labor law entitles women in firms with fifty or more female employees to unpaid leave twice during their entire service; this conflicts with article 
$72 / 3$ of the Child Law which gives women this option three times during their service (ibid.). Such contradictions among the various laws and policies lead to complexities in the implementation of the law and the burden will fall on the intended beneficiaries - i.e. women.

To ensure equity and growth in female participation, more attention must be paid to the coherence and impact of legislation on women's work access and conditions. Such minor changes as proposed in the new labor code are insignificant in changing the gender segmentation in opportunity structures in the market. As female labor force participation grows, clearer policies are required to ensure greater access and better working conditions. Along with the labor code, incentives must be given to employers to hire women, either by contributing towards the cost of benefits for women (such as establishing a nursery), or through other forms of incentive structures.

\section{CONCLUSION}

Policy is the major mechanism that shapes opportunity structures for youth in the economy. Investment policies and labor laws have the most direct impact in creating jobs and influencing work conditions in the market. Egypt has made major strides in reforming its regulatory framework to encourage growth. Investment laws continue to offer greater incentives to foreign and domestic investors and a proposed new labor law aims at removing constraints to private sector growth. While policy reforms may be contributing towards greater growth in the economy, there are serious equity concerns. Women's access to work opportunities in the private sector remains limited by cultural and social biases. With the reform policies, the burden of reform will disproportionately fall on female graduates. Thus, while investment policies are quintessential in creating opportunities for young people in Egypt, special policies targeting young women are important not only on the grounds of equity, but also to reduce unemployment (which is highest among young women) and to foster greater growth.

Three additional points are noteworthy. First, coherence among policies and laws is crucial. To achieve its objectives and have an impact, policies should be clear without ambiguities, and consistent with other laws. Ambiguities and conflicts among the various laws raise disputes and constrain the reform process. Secondly, a commitment to change is not sufficient without concrete measures to achieve such change. It has been four years since the State Council revised the draft of the proposed new labor code. While the delay may be positive in generating further debate and consequently greater consensus among all parties concerned, it can not continue for long. Instead of evading ratification of the law in order not to cause protest among workers, the government should address the issue and ensure a balance between growth needs in the economy and the development and security of labor. A final and important point is implementation. To ensure growth and equity by encouraging investment and protecting workers, laws must be enforced. Without implementation these policies and laws would only be words on paper. 


\title{
Chapter Three
}

\section{Youth and the Labor Market, 1988-1998}

\author{
Safaa El-Tayeb El-Kogali
}

\section{INTRODUCTION:}

This chapter examines characteristics of the labor force in 1998 and changes in the structure of opportunities and working conditions for youth between 1988 and 1998 - a period of major economic and structural reforms. Structural Adjustment Programs (SAPs) are premised on the notion that transition to an open market economy will accelerate economic growth, boost investment and increase the demand for labor. SAPs also maintain that adopting an open market approach will offer greater opportunities and better wages for new entrants into the labor market. Critics argue that since SAPs entail a shrinking role for the public sector, which has been a major absorber of new labor, structural adjustment is likely to lead to increased unemployment. Moreover, despite the emphasis placed on the formal private sector in creating new jobs, in most developing countries, as in Egypt, the contribution of the formal private sector has been slow. They note that the formal private sector does not yet have the ability to create jobs to match the number of new entrants mostly youth -- into the labor market (e.g. Assaad, 1997; Moghadam, 1998; Radwan, 1998). ${ }^{5}$

With the limited role of the formal private sector and the government's shrinking role as the dominant employer, some experts regard the informal sector as the "engine of growth" for future development, offering opportunities for young people entering the labor market (Handoussa and Potter, 1992). Some argue that while the informal sector may offer job opportunities, especially for young women, they are forced to work under unstable and poor conditions (see Standing 1989). Others note that while adjustment programs may create more opportunities in the overall economy, women usually fare. Women are traditionally concentrated in the public sector and in service activities. Since adjustment involves a shifting of resources away from the public to the private sector and from the production of non-tradables (e.g. services) to tradables, women may lose their source of livelihoods during structural adjustment. Given their limited mobility due to cultural biases, women in most cases are pushed into lower jobs with poor conditions or out of the labor market (Moghadham, 1998).

The main question to be addressed in this chapter is how work opportunities and conditions for young people have changed during this period of economic reform and structural adjustment in Egypt. Special attention will be given to gender disparities. The analysis does not attempt to establish a causal relationship between reforms and youth work opportunities, but rather points to the links which may guide further research.

The chapter begins with a brief background sketch of youth in Egypt, followed by definitions of concepts and a description of the data and methodology. Section three gives a recent profile of youth in the labor force. Section four investigates changes in the structure

\footnotetext{
${ }^{5}$ See chapter one for a more detailed discussion on the impact of SAPs on employment.
} 
of labor market opportunities for youth between 1988 and 1998, and identifies emerging

opportunities. Section five observes changes in the conditions of work during the ten-year period. Section six concludes.

\section{BACKGROUND}

According to the 1996 population figures, there are 13.4 million young men and women between the ages of 15 and 24 in Egypt (see table A1 in the appendix for the distribution of youth in Egypt by age, sex and urban/rural residence). At 22.2 percent, youth comprise the largest segment of Egypt's 60 million population. While the relatively large size of the youth population in the current age structure of the total population can be considered a 'window of opportunity' (in terms of low dependency ratios which in other contexts have led to high savings rates), accommodating such a large entering cohort into the labor market poses a challenge for growth. It is estimated that there are 500,000 new entrants into the labor market annually who are predominantly young with intermediate level schooling (Radwan, 1998). As we have mentioned previously up until the mid-1980s, most of the new entrants were absorbed by the government through the Graduate Employment Scheme which had been established in the early 1960s. While the scheme may have boosted the demand for education and encouraged female labor force participation, it has left an oversized public sector and high aspirations amongst young Egyptians for a guaranteed government job with life-long security and benefits.

Opportunities for formal employment in the emerging private sector were inferior in size and benefits to the public sector and did not offer attractive opportunities for these graduates. Thus, the majority of those who remained in the labor force ended up in the informal sector - in disguised unemployment or underemployment-or joined the ranks of the openly unemployed. With the recession in the late 1980s, and the structural reforms adopted in the early 1990s, unemployment among young new entrants soared. The latter half of the 1990s showed positive signs of growth in the economy. Whether such growth is matching the demand for work opportunities for the growing number of youth is the real question; what and where these opportunities are will be explored in this study.

\section{Definitions , Data, And Methodology}

\section{Definitions}

Youth are defined as young men and women between the ages of 15 and 24 years. The choice of this age range is justified on the grounds that it marks a critical period of transition from childhood to adulthood. It is the skills and opportunities offered at this stage which determine the future of young men and women as adults (see chapter one).

The labor force is defined as the economically active population. In general, economic activity is defined as "the production and processing of primary products whether for the market, for barter, or for own consumption, the production of all other goods and services for the market, and in the case of households that produce such goods and services for the market, the corresponding production for own consumption." (cited in Assaad, 1999). The survey data excludes from the labor force persons who are full time students, 
housewives, retirees, temporarily or permanently disabled, older than 64 , members of the armed forces who are not working in the civilian labor force, and persons who do not desire to engage in an economic activity. In this study, the definition of economic activity is limited to production of a good or service for the market. This definition excludes all subsistence and non-market work. Such exclusions are justified on the grounds that they allow a focus on emerging opportunities and capture the dynamics of the economy that an undifferentiated definition of all work would not allow. The focus of this study is on the changing structure of opportunities in paid work in the labor market. The exclusion of subsistence work is by no means an under-estimation of such work.

The labor force consists of employed and unemployed persons between the ages of 15 and 64. Various definitions of employment and unemployment are used in the literature. The broadest definition of employment consists of all economic activity whether for the market or subsistence. Some definitions include a specific number of hours, others exclude subsistence. In this study, employment is defined on the basis of participation in the production of a good or service for the market - i.e. for production and not consumption-for at least one hour during the reference week. It includes wage work, self-employment and unpaid family work.

Unemployment is defined in terms of open unemployment and discouraged unemployment. Open unemployment applies to the economically active population who are not in employment. It involves the desire and readiness for employment and in this study also includes active search for employment. ${ }^{6}$ This is the definition most commonly used in Egypt, although it was not used in the 1988 Special Round of the Labor Force Sample Survey. Discouraged unemployment is defined as seeking work and available to work but not actively searching. Where applicable, the search criteria may be dropped to get full information on labor availability and to reveal discouraged unemployment, which is most likely the case among females.

\section{Data}

In the past, a major problem in measuring changes over time had been the incomparability of data due to the different methodologies and definitions used by various researchers. However, we have a unique opportunity for comparing data on the labor market over two periods of time. The Egypt Labor Market Survey (ELMS), conducted by the Economic Research Forum for Arab Countries, Turkey and Iran (ERF) in collaboration with the Central Agency for Public Mobilization and Statistics (CAPMAS), was designed using a similar sample and instruments as the Special Round of the Labor Force Sample Survey (LFSS) undertaken in October 1988. The ELMS was carried out in October 1998 -- exactly ten years after the LFSS. In an effort to maximize gains and foster cooperation in research, the Population Council regional office for West Asia and North Africa (WANA) agreed with the ERF to incorporate our study instruments for the youth livelihoods project within the ELMS instruments. This allowed measurement of changes in the labor market in general, and

\footnotetext{
${ }^{6}$ The ELMS98 defines "wishing to work" as willing to start working within 15 days if work becomes available. The reference period for "seeking to work" was set at 3 months, except for those who are registered for public employment who were considered to be seeking work even if their registration was prior to the 3 month reference period (Assaad, 1999).
} 
the situation of youth in particular, over the past ten years. ${ }^{7}$ Efforts were taken to ensure the highest quality of data collected. Quality control and monitoring were done at the various stages from training of field staff to fieldwork, handling of completed questionnaires, and data coding, checking, entry and validation. ${ }^{8}$

The 1998 sample used for the analysis is nationally representative at the regional level, and consists of 5000 households in 200 primary sampling units (PSU). The desired number of PSUs in each governorate was selected from a master sample using a systematic interval. Cairo and Alexandria were deliberately over-sampled and rural areas undersampled to increase the probability of obtaining women wage-workers in the private sector, which tend to be concentrated in metropolitan areas. A self-weighted sample would have yielded too few of these individuals, who constitute a major target group for our study. Baseline data is used from the 1988 LFSS, which is also nationally representative.

The 1998 sample has a total of 23,997 individual observations of which 21.6 percent $(5,175)$ are youth between the ages 15 and 24 (2737 males and 2438 females). The 1988 sample used has a total of 28,286 individual observations of which 19.8 percent $(5,597)$ are youth (2888 males and 2709 females). The section on the Profile of Youth in the Labor Force is entirely based on the 1998 data set, whereas, the sections on evolving opportunities for youth and working conditions in the labor market use both the 1988 and 1998 data sets.

\section{Methodology}

Changes in the structure of work opportunities for youth will be analyzed through changes in their work status, sectoral distribution, economic activity, and occupational distribution, between 1988 and 1998. Shifts within sectors, economic activity and occupations during the two periods will also give an indication of where opportunities are emerging.

Changes in the quality of work will be analyzed through working conditions including average hours of work per week, availability of a contract, social security and medical insurance. Changes in the proportion of youth working in and out of establishments will also be observed; jointly with the above indicators for working conditions in/out of establishment may also give an indication of work formality - movements between the formal and informal sectors.

Numbers and proportions used throughout the study are weighted using 1998 population statistics to correct for the over-sampling and to reflect actual population proportions.

\section{A Profile of Youth in the Labor Force in EgyPT}

Table 1 shows labor force participation rates and population estimates of youth aged 15 to 24 in Egypt in 1998. As the table shows, 4.3 million or 31.8 percent of Egyptian youth are in the labor force, either in employment or unemployed and actively searching for employment. They constitute 23.7 percent of the total labor force (15-64) in Egypt. Labor

\footnotetext{
${ }^{7}$ See Assaad and Barsoum, 1999 for details on ELMS.

${ }^{8}$ See Assaad and Barsoum, 1999 for details of sample design, field work and quality control.
} 
force participation varies widely among youth by gender, age and urban/rural residence. The participation rate for young women is 19.3 percent and 43.0 percent for young men. Among younger youth (adolescents between the ages of 15 and 19) on average, a third of boys are in the labor force compared to 10.6 percent of girls in the same age group. As for older youth (ages 20 to 24) on average over half of young men (55.2) and about a third (31.6) of young women are in the labor force. Despite the large gender disparity, the gender gap is narrower among youth than for the overall labor force population where the labor force participation rate for men ages 15 to $64(72.3 \%)$ is more than three times the participation rate for women $(21.2 \%){ }^{9}$

\footnotetext{
${ }^{9}$ The labor force participation rate (LFPR) measures the proportion of the population participating in the labor force over the total economically active population: The youth LFPR is measured as $\mathrm{fY}_{\mathrm{lf}}+\mathrm{mY}_{\mathrm{lf}} / \mathrm{Y}_{\mathrm{f}+\mathrm{m}}$ where $\mathrm{fY}_{\mathrm{lf}}$ and $\mathrm{mY}_{\mathrm{lf}}$ are the number of female and male youth in the labor force, respectively and $\mathrm{Y}_{\mathrm{f}+\mathrm{m}}$ is the total youth population ages 15 to 24 .
} 
Table 1 Labor Force Participation Rates of Youth (ages 15 to 24) in Egypt, 1998

\begin{tabular}{|c|c|c|c|}
\hline & $\begin{array}{l}\text { Male } \\
\%\end{array}$ & $\begin{array}{c}\text { Female } \\
\%\end{array}$ & $\begin{array}{c}\text { Total } \\
\%\end{array}$ \\
\hline $15-19$ & 33.4 & 10.6 & 22.4 \\
\hline $20-24$ & 55.2 & 31.6 & 44.3 \\
\hline $15-24$ & 43.0 & 19.3 & 31.8 \\
\hline $15-64$ & 72.3 & 21.2 & 46.8 \\
\hline
\end{tabular}

Source: ELMS, 1998

\section{Youth Labor Force Participation By Urban/Rural and Region of Residence}

Table 2 shows labor force participation rates of youth aged 15 to 24 in Egypt in 1998, by urban/rural and region of residence. As the table shows, youth labor force participation is higher in rural areas $(33.8 \%)$ than in urban areas $(28.8 \%)$. While the female participation rate is similar in urban and rural areas (19.6 and 19.2 percent, respectively), male rates are 47.1 percent in rural areas and 37.0 percent in urban areas. The lower participation rates for young men in urban areas may be interpreted as more limited opportunities in urban areas than in rural areas, but it may also be partly explained by higher school enrollment in urban areas as compared to rural areas (see table A2 in appendix). The highest labor force participation rate for youth is in rural Lower Egypt at 36.5 percent and the lowest is in Alexandria and Suez Canal cities at 26.6 percent. Male participation rates drive the overall rate: the highest rates are in rural Egypt both Lower and Upper and the lowest rates are in Greater Cairo, Alex and the Suez Canal cities. The highest participation rates for female youth are in Lower Egypt, both urban and rural, and the lowest rate is in rural Upper Egypt.

Table 2 Urban/Rural and Regional Distribution of Labor Force Participation Rates of Youth (ages 15 to 24) in Egypt, 1998

\begin{tabular}{|c|c|c|c|}
\hline & Male & Female & Total \\
\hline Urban & 37.0 & 19.6 & 28.8 \\
\hline Rural & 47.1 & 19.2 & 33.8 \\
\hline Greater Cairo & 34.2 & 18.7 & 27.0 \\
\hline Alex. \& Canal Cities & 34.1 & 18.7 & 26.6 \\
\hline Urban Lower Egypt & 41.9 & 22.3 & 32.4 \\
\hline Urban Upper Egypt & 39.9 & 18.4 & 30.3 \\
\hline Rural Lower Egypt & 49.0 & 22.9 & 36.5 \\
\hline Rural Upper Egypt & 44.6 & 13.7 & 30.1 \\
\hline Total Egypt & 43.0 & 19.3 & 31.8 \\
\hline
\end{tabular}

Source: ELMS, 1998

\section{Youth Labor Force Participation By Age}

Figure 1 shows labor force participation among youth distributed by age. While participation increases with age for both young men and women, male participation shows sharper fluctuations across age than female participation. The sharp increase for young men at age 18 is probably marked by the end of secondary school and the entry of a large proportion of young men into the labor force. The sharp drop between ages 20 and 21 is most likely due to mandatory military service. 
Figure 1. Labor Force Participation of Youth (ages 15 to 24) in Egypt, by Age and Sex, 1998

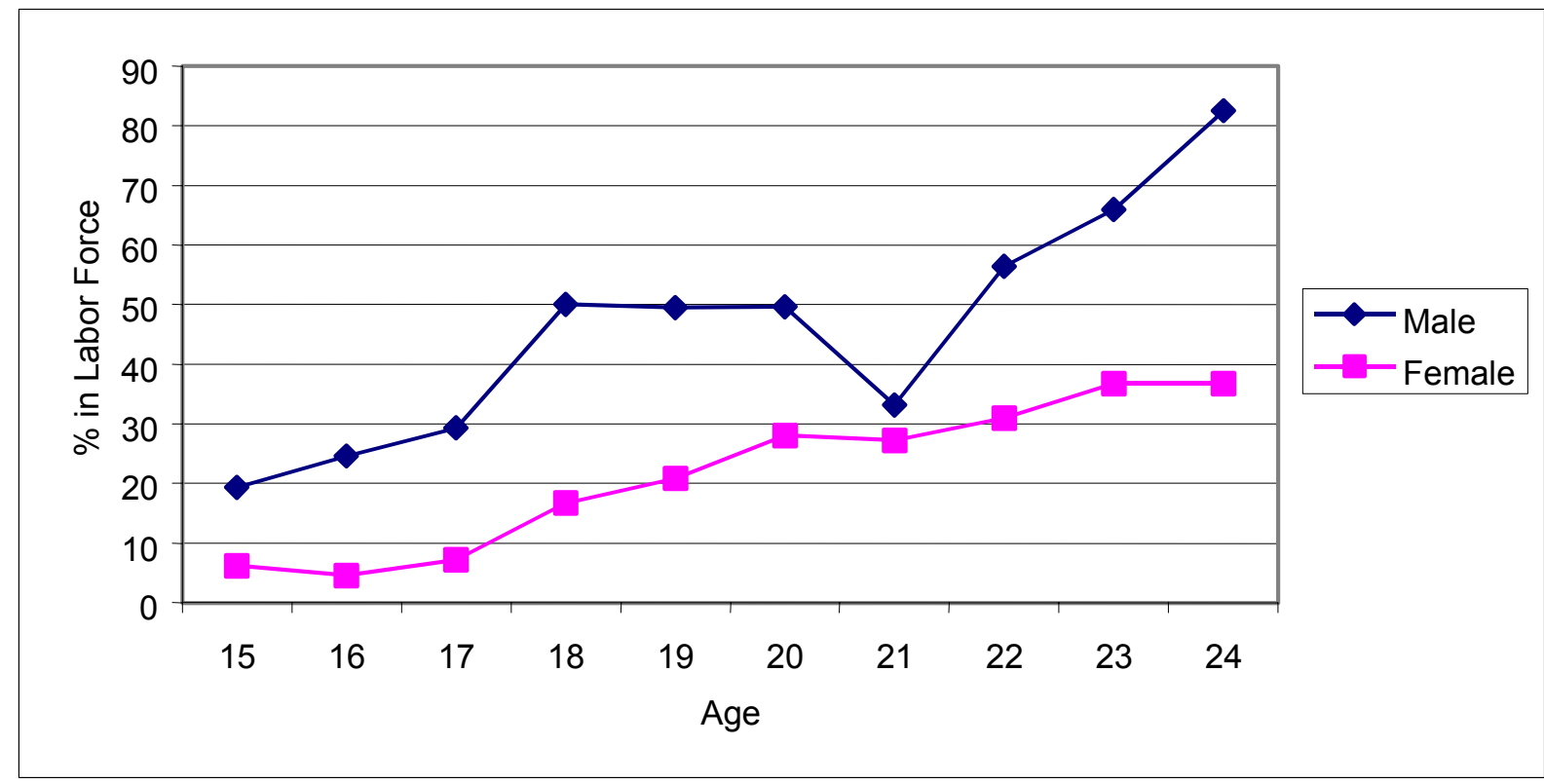

Source: ELMS, 1998

On average the working population in Egypt enters the labor force during their youth - i.e. between ages 15 and 24. Observing the average age of entry into the labor force for the working population ages 25 to 64 shows the average age of entry for men is 16.6 years and for women, 22.2 years. ${ }^{10}$

Figure 2 shows an interesting pattern for men and women: younger generations of men appear to be entering the labor force later than the older generations and younger generations of women are entering earlier. Various supply and demand factors may be causing this pattern. An important factor that may explain the delay in entry for younger men is education: younger generations of men are staying longer in school (see box on education trends below). For women, earlier entry for younger generations may be partly due to more opportunities in the labor market for women, fewer socio-cultural restrictions on female mobility or delayed marriage age. In a recent study of determinants of female labor force participation in Egypt Assaad and El-Hamidi found that "[b]eing unmarried, has a positive and significant effect on overall participation" (Assaad and El-Hamidi, 1999:12). During the past few decades, the age of marriage for women in Egypt has been increasing which may also explain the earlier entry of the younger generations of women into the labor force. $^{11}$

\footnotetext{
${ }^{10}$ The age group 15 to 24 is excluded due to incomplete exposure to labor force participation (mainly caused by education and military service).

${ }^{11}$ See Asaad and El-Hamidi, 1999 for more on determinants of female labor force participation in Egypt.
} 
Figure 2. Average Age of Entry into the Labor Force in Egypt, by Sex, 1998

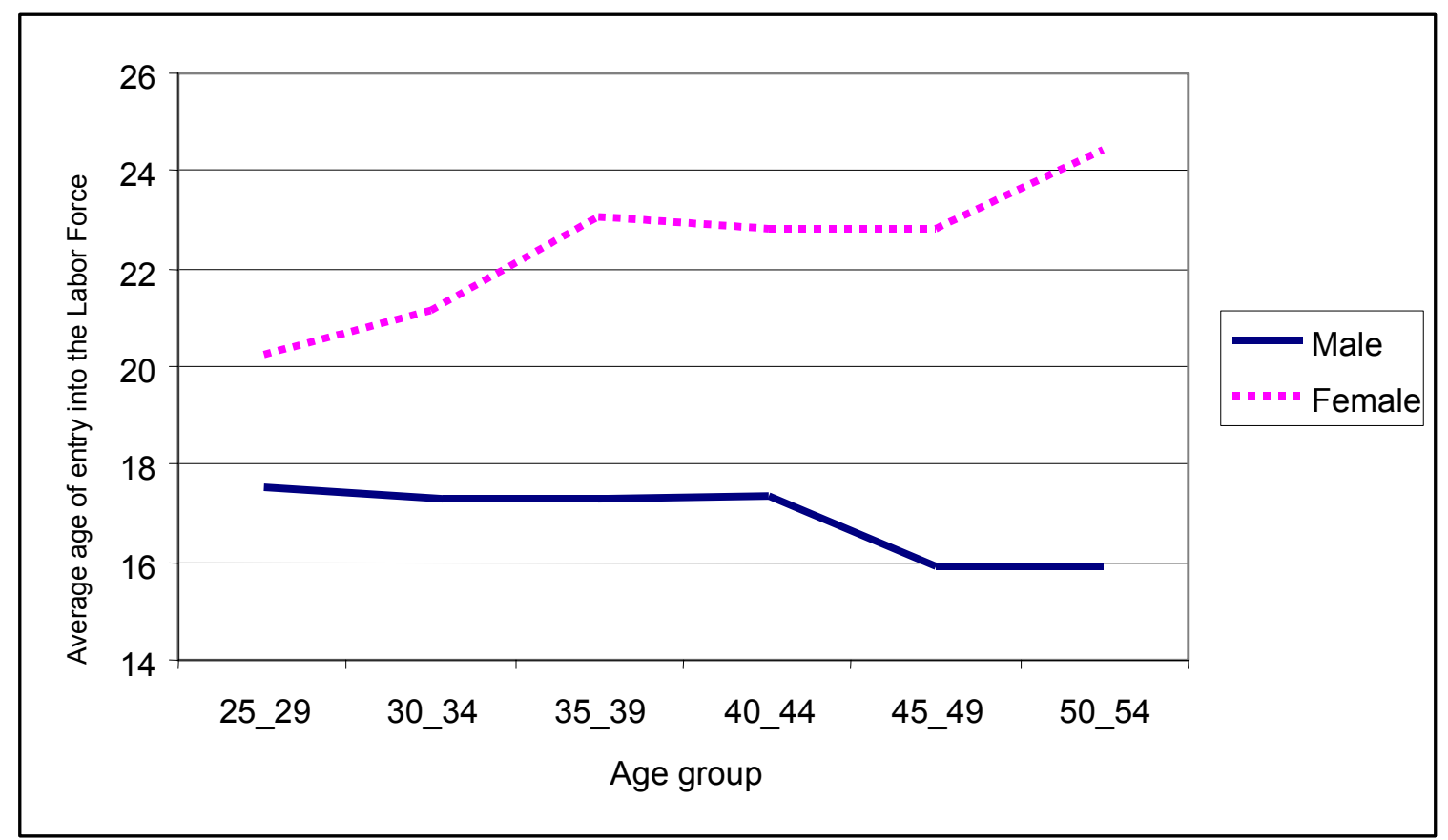

Source: ELMS, 1998

\section{Youth Labor Force Participation by Level of Education}

Table 3 shows the level of education attained by youth in the labor market who have ever been to school -- either completed school or dropped out. More than half of youth in the labor market who have ever been to school have at least intermediate level education, but 19.1 percent are illiterate and only 7.6 percent have university and above education. There are also significant gender differences. The education distribution of male youth in the labor market is more even than among female youth, where the concentration is among those with intermediate education. 


\section{TRENDS IN YOUTH EDUCATION IN EGYPT}

There has been tremendous development in education in Egypt during the past decade - especially in girls' schooling. The percentage of youth (ages 15 to 24) enrolled in school increased by almost 15 percent between 1988 and 1998 from 36.2 percent to 41.5 percent. This was mostly due to the 40 percent increase in female enrollments from 27.2 percent in 1988 to 38.2 percent in 1998.

The advance in schooling during the past decade is clearly reflected in the changes in educational status of youth between 1988 and 1998. Illiteracy among youth dropped by more than half, from 34.0 percent in 1988 to 16.5 percent in 1998. The proportion of youth with limited education (read and write) also dropped by over a third between 1988 and 1998 from 6.9 percent to 4.2 percent, while the proportion of those with primary education and above increased. Another positive trend is that more youth are staying in school longer as shown by the 56 percent increase in intermediate education. Intermediate education seems to be the end point of education for most youth, but those who do continue to the secondary level, are likely to continue to university. The proportion of youth with university education increased by over a third between 1988 and 1998 and the growth rate is higher among young women than young men. Between 1988 and 1998 the proportion of young women with university education increased from 2.1 percent to 3.4 percent and for young men from 2.5 percent to 2.8 percent.

Despite the positive trends, much remains to be done. 10.5 percent of youth have never been to school - 16.7 percent of young women and 4.8 percent of young men, and 18.6 percent drop out before completing intermediate level education.

Source: LFSS, 1988 and ELMS, 1998

Table 3 Education Level of Youth (ages 15 to 24) Not in School and in the Labor Force in Egypt, 1998

\begin{tabular}{|c|c|c|c|}
\hline Education Level & Male & Female & Total \\
\hline Illiterate & 21.9 & 12.2 & 19.1 \\
\hline Reads \& Writes & 9.2 & 2.8 & 7.3 \\
\hline Less than Intermediate & 22.1 & 7.2 & 17.7 \\
\hline Intermediate & 38.7 & 55.1 & 43.5 \\
\hline Above Intermediate & 3.1 & 9.1 & 4.8 \\
\hline University \& Higher & 5.1 & 13.6 & 7.6 \\
\hline Total & 100.1 & 100.1 & 100.0 \\
\hline $\mathrm{N}$ (weighted) & 1091 & 453 & 1544 \\
\hline
\end{tabular}

Source: ELMS, 1998

Figure 3 shows labor force participation of young men and women by the level of education completed. The graph tells an interesting story about the relationship between education and labor force participation of young men and women in Egypt. First, it appears that education has a much higher influence on the participation of young women than young men. Participation of young women is constant among those with less than intermediate education and rises sharply for young women with intermediate level education and above. Participation of male youth is more or less the same across the various education levels. 
Secondly, the gap in participation among illiterate male and female youth is very large but tends to decrease sharply after the intermediate level of education, such that equal proportions of men and women with university degrees are in the labor force.

Figure 3. Labor Force Participation of Youth (ages 15 to 24) in Egypt, by Sex and Level of Education Completed, 1998

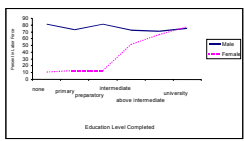

Source: ELMS, 1998

\section{Youth Labor Force Participation by Marital Status}

The minimum legal age for marriage in Egypt is 16 years for women and 18 years for men. Table 4 shows the marital status of youth in the labor force in Egypt by sex and urban/rural residence. The majority of youth in the labor force are single. There are however wide gender and urban/rural disparities. While only 10 percent of male youth in the labor force are or have been married, about a quarter of female youth in the labor force are married or have been married in the past. As rural women tend to marry earlier than their urban sisters, almost a third of female youth living in rural areas are or have been married.

Table 4 Marital Status of Youth (ages 15 to 24) in the Labor Force in Egypt, by Sex and Urban/Rural Location, $1998^{12}$

\begin{tabular}{|c|c|c|c|c|c|c|}
\hline & \multicolumn{3}{|c|}{ Female } & \multicolumn{3}{|c|}{ Male } \\
\hline & Urban & Rural & Total & Urban & Rural & Total \\
\hline Never Married & 87.2 & 69.2 & 76.8 & 92.5 & 88.3 & 89.8 \\
\hline Ever Married* & 12.8 & 30.8 & 23.2 & 7.5 & 11.7 & 10.2 \\
\hline Total & 100.0 & 100.0 & 100.0 & 100.0 & 100.1 & 100.0 \\
\hline $\mathrm{N}$ (weighted) & 193 & 263 & 456 & 352 & 579 & 931 \\
\hline
\end{tabular}

Source: ELMS 1998

Note: * Ever married includes married, legally married, divorced and widowed.

Youth Labor Force Participation by Household Characteristics

Most youth in the labor force come from medium size households with 5 to 7 members. However, a larger proportion of young men who come from large households (8 members or more) are in the labor force than those who come from small or medium size households. Conversely, a smaller proportion of young women who come from large households participate in the labor force than young women who come from small or medium households. It may be that large households would require young men to go out and work while young women stay and help with household chores. ${ }^{13}$ (See Tables A3 and A4 in

\footnotetext{
${ }^{12}$ These proportions are for men ages 18-24 and women ages 16-24 in the labor force.

${ }^{13}$ Classification used in ASCE report, 1999 where small households have between 1 to 4 members, medium households have between 5 to 7 members and large households have 8 or more members.
} 
the appendix).

\section{Youth Work Status}

Table 5 shows the work status of youth and the overall population in the labor force in Egypt in 1998. 69.4 percent of youth in the labor force are employed (in wage work, selfemployment or unpaid family work), constituting about a fifth of all employed persons in the labor force. There is a large gender gap in youth employment. Twice as many young men as young women are in employment -81.0 percent of young men compared to 40.6 of young women.

Youth in Egypt carry the largest burden of unemployment. They constitute over 60 percent of the unemployed persons in the labor force in Egypt. At an open unemployment rate of 30.6 percent, youth unemployment is almost three times the overall unemployment rate in Egypt (11.7\%). These rates yield a national estimate of 1.3 million young men and women who are able, ready, and searching for work. The situation for young women is much worse than for their older sisters and their fellow young men. The open unemployment rate for female youth is 59.4 percent - almost three times the rate for male youth (19.0 percent) and more than twice the overall female unemployment rate (27.6 percent). That is more than half the young women in the labor force are unemployed and seeking employment.

Table 5 Work Status of Youth (ages 15 to 24) and Overall Population (15-64) in the Labor Force in Egypt, by Sex, 1998

\begin{tabular}{|c|c|c|c|}
\hline & $\begin{array}{c}\text { Employed } \\
\%\end{array}$ & $\begin{array}{c}\text { Unemployed } \\
\%\end{array}$ & $\begin{array}{r}\text { Total } \\
\%\end{array}$ \\
\hline \multicolumn{4}{|l|}{ Male } \\
\hline $15 \_24$ & 81.0 & 19.0 & 100.0 \\
\hline $15 \_64$ & 93.0 & 7.0 & 100.0 \\
\hline \multicolumn{4}{|l|}{ Female } \\
\hline $15 \_24$ & 40.6 & 59.4 & 100.0 \\
\hline 15_64 & 72.4 & 27.6 & 100.0 \\
\hline \multicolumn{4}{|l|}{ Total } \\
\hline $15 \_24$ & 69.4 & 30.6 & 100.0 \\
\hline $15 \_64$ & 88.3 & 11.7 & 100.0 \\
\hline
\end{tabular}

Source: ELMS, 1998

As mentioned earlier in the chapter, dropping the search criterion can give an indication of discouraged unemployment, i.e. those persons who were available and ready to work but have not actively searched for work during the three months that end with the reference week. As Table 6 shows, relaxing the search criterion, the unemployment rate for the overall population in the labor force declines by 0.3 percentage points. However, the youth unemployment rate declines by 2 percentage points to 28.8 percent - mostly due to a 6.5 percentage point decline in the female youth unemployment rate. These results suggest that a large proportion of young women who were ready and willing to work stopped looking for employment - more than men in their age group and women in older age groups in the labor force. 
Table 6 Distribution of Labor Force in Egypt, by Work Status, Sex and Age, Using Definition of Unemployment Without Search Criterion, 1998

\begin{tabular}{lccccc}
\hline & & Employed & Unemployed & Don't Desire & Total \\
\hline Male & & & & & \\
& 15_24 & 77.8 & 18.3 & 3.9 & 100.0 \\
\multirow{2}{*}{ Female } & 15_64 & 91.5 & 6.9 & 1.6 & 100.0 \\
& 15_24 & 36.1 & 52.9 & 11.0 & 100.0 \\
& 15_64 & 68.6 & 26.2 & 5.2 & 100.0 \\
Total & 15_24 & 65.1 & 28.8 & 6.1 & 100.0 \\
& $15 \_64$ & 86.2 & 11.4 & 2.4 & 100.0 \\
\hline
\end{tabular}

Source: ELMS 1998

\section{Youth Employment}

Table 7 shows the status of employment of youth in the labor force in Egypt in 1998.

Table 7 Employment Status of Youth (ages 15 to 24) in the Labor Force in Egypt, by Sex, 1998

\begin{tabular}{|c|c|c|c|}
\hline & $\begin{array}{l}\text { Male } \\
\%\end{array}$ & $\begin{array}{c}\text { Female } \\
\%\end{array}$ & $\begin{array}{l}\text { Total } \\
\%\end{array}$ \\
\hline Waged employee & 70.1 & 73.7 & 70.7 \\
\hline Employer & 3.2 & 1.0 & 2.8 \\
\hline Self employed & 4.8 & 2.5 & 4.4 \\
\hline Unpaid working for family & 21.9 & 22.9 & 22.1 \\
\hline Total employment & 100.0 & 100.0 & 100.0 \\
\hline
\end{tabular}

Source: ELMS, 1998

As the table shows, the majority of employed youth are waged employees -70.1 percent of males and 73.7 percent of females. 22.1 percent are engaged in unpaid family work and the remaining 7 percent are mostly self-employed, plus a few employers.

Given the objective of this study the rest of this chapter is to investigate livelihood opportunities remunerative employment. This includes the categories: wage work, employer and self-employment. Given the small proportion of youth working as employers and in selfemployment, the focus will be on wage work. 


\section{EVOLVING OPPORTUNITIES IN THE LABOR MARKET}

This section aims to observe changes in the structure of youth wage employment between 1988 and 1998, and to map emerging opportunities in the economy. Gender and urban/rural disparities will be observed as well as differences between youth and the overall working population (ages 15 to 64).

Table 8 shows the changes in wage work for youth and the overall working population by sex. Between 1988 and 1998, wage work grew at a slower rate for youth than for the overall population, with wide gender and urban/rural differences. The proportion of youth wage workers increased from 46.0 percent in 1988 to 48.4 percent in 1998, while for the overall population, the proportion of wage workers grew from 50.6 percent to 54 percent during the decade. However, a breakdown by gender and age shows that this growth of wage work as a proportion of all work was driven by growth in male wage work. Overall, the proportion of wage workers among women declined, and more so among young women, falling from 26.7 percent in 1988 to 19.6 percent in 1998 . Given the increase among men and decline among women wage workers, the gender gap in wage work increased during the ten-year period. The ratio of females to males among wage workers in 1988 was 0.45 . In 1998 the female to male ratio became 0.39 . The gender gap among young workers age 15-24 was even wider falling for 0.38 to 0.28 .

Table 8 Distribution of Workers in Egypt, by Wage/Nonwage work, Age and Sex, 19881998

\begin{tabular}{|c|c|c|c|c|c|c|}
\hline & \multicolumn{3}{|c|}{1988} & \multicolumn{3}{|c|}{1998} \\
\hline & Male & Female & Total & Male & Female & Total \\
\hline \multicolumn{7}{|l|}{$15 \_24$} \\
\hline Wage work & 58.7 & 26.7 & 46.0 & 70.0 & 19.6 & 48.4 \\
\hline Nonwage work & 41.3 & 73.3 & 54.0 & 30.0 & 80.4 & 51.6 \\
\hline Total & 100.0 & 100.0 & 100.0 & 100.0 & 100.0 & 100.0 \\
\hline N (weighted) & 1206 & 801 & 2007 & 870 & 652 & 1522 \\
\hline \multicolumn{7}{|l|}{$15 \_64$} \\
\hline Wage work & 62.6 & 28.2 & 50.6 & 70.6 & 27.2 & 54.0 \\
\hline Nonwage work & 37.4 & 71.8 & 49.4 & 29.4 & 72.8 & 46.0 \\
\hline Total & 100.0 & 100.0 & 100.0 & 100.0 & 100.0 & 100.0 \\
\hline $\mathrm{N}$ (weighted) & 5624 & 3018 & 8642 & 4817 & 2976 & 7793 \\
\hline
\end{tabular}

Source: LFSS, 1988 and ELMS, 1998

\section{Changes in the Distribution of Youth Wage Workers by Residence}

Table 9 shows the distribution of youth wage workers by urban/rural and region of residence in Egypt in 1988 and 1998. The table shows that between 1988 and 1998, there was a significant shift in the concentration of youth wage workers from urban to rural areas among youth wage workers - particularly among female youth. The change is mainly due to a decline in the proportion of youth wage workers in the traditional urban centers: Greater Cairo, Alexandria and the Suez Cities, despite the significant increase in urban Lower and urban Upper Egypt. Rural Lower Egypt has the largest proportion of youth wage workers -36.6 percent of young men and 33.5 percent of young women. Greater Cairo has the second highest concentration of female youth wage workers accounting for over a fifth of total 
young female wage workers. For young male wage workers, rural Upper Egypt has the second highest concentration, with a quarter of young men in wage work. Changes in the urban-rural distribution of youth wage workers need to be investigated. It may be due to the fact that most returned migrants from the gulf made investments in rural areas which offered greater opportunities for youth wage employment. It may also be a shift in residence and not necessarily of work. That is more young people may be living in rural areas but commuting to work in urban areas. Observing job location versus residence in 1988 and 1998, shows a greater proportion of youth in 1998 than in 1988 who are living in rural areas and commuting to urban areas for work. Moreover, the decline among urban youth wage workers may also be due to a significant drop in public sector employment as a result of the privatization efforts during the decade. This will be investigated in the next section.

Table 9 Distribution of Youth Wage Workers (ages 15 to 24) in Egypt, by Sex, Urban/Rural and Region of Residence, 1988-1998

\begin{tabular}{|c|c|c|c|c|c|c|}
\hline & \multicolumn{3}{|c|}{1988} & \multicolumn{3}{|c|}{1998} \\
\hline & Male & Female & Total & Male & Female & Total \\
\hline \multicolumn{7}{|l|}{ Urban/Rural } \\
\hline Urban & 44.2 & 61.9 & 48.3 & 38.0 & 52.6 & 40.5 \\
\hline Rural & 55.8 & 38.1 & 51.7 & 62.0 & 47.4 & 59.5 \\
\hline Total & 100.0 & 100.0 & 100.0 & 100.0 & 100.0 & 100.0 \\
\hline N (weighted) & 720 & 217 & 937 & 670 & 140 & 810 \\
\hline \multicolumn{7}{|l|}{ Region } \\
\hline Greater Cairo & 23.7 & 36.1 & 26.6 & 15.7 & 22.8 & 16.9 \\
\hline Alex. \& Canal Cities & 8.1 & 13.1 & 9.2 & 5.9 & 12.2 & 7.0 \\
\hline Urban Lower Egypt & 8.2 & 10.1 & 8.6 & 10.3 & 10.5 & 10.3 \\
\hline Urban Upper Egypt & 4.2 & 2.6 & 3.8 & 6.2 & 7.1 & 6.3 \\
\hline Rural Lower Egypt & 27.0 & 29.7 & 27.6 & 36.6 & 33.5 & 36.1 \\
\hline Rural Upper Egypt & 28.8 & 8.4 & 24.1 & 25.4 & 13.9 & 23.4 \\
\hline Total & 100.0 & 100.0 & 100.0 & 100.0 & 100.0 & 100.0 \\
\hline N (weighted) & 720 & 217 & 937 & 670 & 140 & 810 \\
\hline
\end{tabular}

Source: LFSS, 1988 and ELMS, 1998

\section{Changes in the Sectoral Distribution of Youth Wage Workers}

The private sector is the leading sector for youth wage workers in Egypt. In 1998, 81.7 percent of young men and women wage workers were engaged in private sector activity and 18.2 percent were in the public sector (government and public enterprises) and $0.1 \%$ in other activities (joint enterprises etc.). The distribution varies by gender: Female youth were more evenly distributed between the private and public sectors - 58.2 and 41.2 percent, respectively, while male youth wage workers were more concentrated in the private sector86.6 percent compared to 13.3 percent in the public sector (see table A5 in the appendix). 
Table 10 shows the distribution of youth wage workers by sex and sector in 1988 and 1998. The public sector is classified into government work and state-owned enterprises (SOEs). The private sector is also classified as agricultural and non-agricultural to better observe where changes are taking place within the sector. As the table shows, between 1988 and 1998, there were significant changes in the distribution of youth wage workers between sectors. The proportion of youth working in private sector agricultural wage work declined significantly from 21.2 percent in 1988 to 13.4 percent in 1998 . The proportion of youth working in state-owned enterprises (SOEs) also declined falling from 7.1 percent to 4.1 percent. The decline in SOE work probably drives the significant drop among urban youth wage workers as noted above. Opportunities for youth appear to have emerged to some extent in government, increasing from 12.3 to 14.1, and in the non-agricultural private sector which increased from 59 percent to 68.4 percent.

Table 10 Distribution of Youth Wage Workers (ages 15 to 24) in Egypt, by Sex and Sector, 1988-1998

\begin{tabular}{|c|c|c|c|c|c|c|}
\hline & \multicolumn{3}{|c|}{1988} & \multicolumn{3}{|c|}{1998} \\
\hline & Male & Female & Total & Male & Female & Total \\
\hline Government & 6.9 & 30.5 & 12.3 & 8.8 & 39.5 & 14.1 \\
\hline State-Owned Enterprises & 5.6 & 14.0 & 7.6 & 4.5 & 2.0 & 4.1 \\
\hline Private Agri Wage work & 22.2 & 17.7 & 21.2 & 14.3 & 9.4 & 13.4 \\
\hline Private Non-Agri Wage work & 65.3 & 37.8 & 59.0 & 72.4 & 49.1 & 68.4 \\
\hline Total & 100.0 & 100.0 & 100.0 & 100.0 & 100.0 & 100.0 \\
\hline N (weighted) & 717 & 215 & 932 & 668 & 140 & 808 \\
\hline
\end{tabular}

Source: LFSS, 1988 ELMS, 1998

Changes in the sectoral distribution of youth were much more significant among female youth than male youth. Young women were strongly hit with the privatization of SOEs resulting in a drop from 14 to 2 percent among young women working in SOEs between 1988 and 1998, compared to a drop from 5.6 to 4.5 percent in the proportion of young men. Similarly, the proportion of young women in private sector agricultural wage work fell from 17.7 percent to 9.4 percent while for men the decline was from 22.2 percent to 14.3 percent. The increase in the proportion of youth working for the government increased for both young men and women between 1988 and 1998 at a similar rate. In the nonagricultural private sector, opportunities appear to have grown more for young women that for young men: The proportion of female youth in nonagricultural private sector work grew from 37.8 to 49.1 percent during the ten-year period compared to an increase from 65.3 to 72.4 for young men. However, the increase in government work and nonagriculture private sector work was not sufficient to absorb the decline in SOEs and private sector agricultural work which explains the significant drop in wage work for young women observed earlier.

\section{Changes in the Structure of Economic Activity for Youth Wage Workers}

This section will analyze changes in the economic activity of youth wage workers between 1988 and 1998. Changes will be observed within the private and public sectors, and differentiated by gender. 
Table 11 Distribution of Youth Wage Workers (Ages 15 to 24) in the Private Sector in Egypt, by Economic Activity, 1988-1998

\begin{tabular}{lcc}
\hline & 1988 & 1998 \\
\hline Agriculture & 26.4 & 16.4 \\
Manufacturing & 26.4 & 27.2 \\
Construction & 17.8 & 19.8 \\
Trade & 16.5 & 17.2 \\
Electric & 0.1 & N/A \\
Mining & 0.5 & N/A \\
Transport & 2.8 & 6.3 \\
Finance & 0.4 & 1.8 \\
Services & 9.1 & 11.4 \\
Total & 100.0 & 100.0 \\
N (weighted) & 740 & 644 \\
\hline
\end{tabular}

Source: LFSS, 1988, ELMS, 1998

Table 11 shows the distribution of youth wage workers in the private sector by economic activity in 1988 and 1998. As the table shows, manufacturing was the leading wage activity for youth in the private sector in Egypt with over a quarter youth wage workers. Construction, trade and services also have a significant proportion of youth. Agriculture which was a leading activity in 1988 for youth along with manufacturing, declined sharply as mentioned earlier and ranked fourth among private sector activities for youth in 1998. The overall picture conceals major gender differences in the structure of economic activities among youth wage workers. Figure 6 below shows the structure and changes in economic activity of male and female wage workers in the private sector in Egypt in 1988 and 1998 (also see table A6 in appendix).

Figure 6. Structure of Economic Activity of Male and Female Youth Wage Workers in the Private Sector in Egypt, 1988 and 1998.

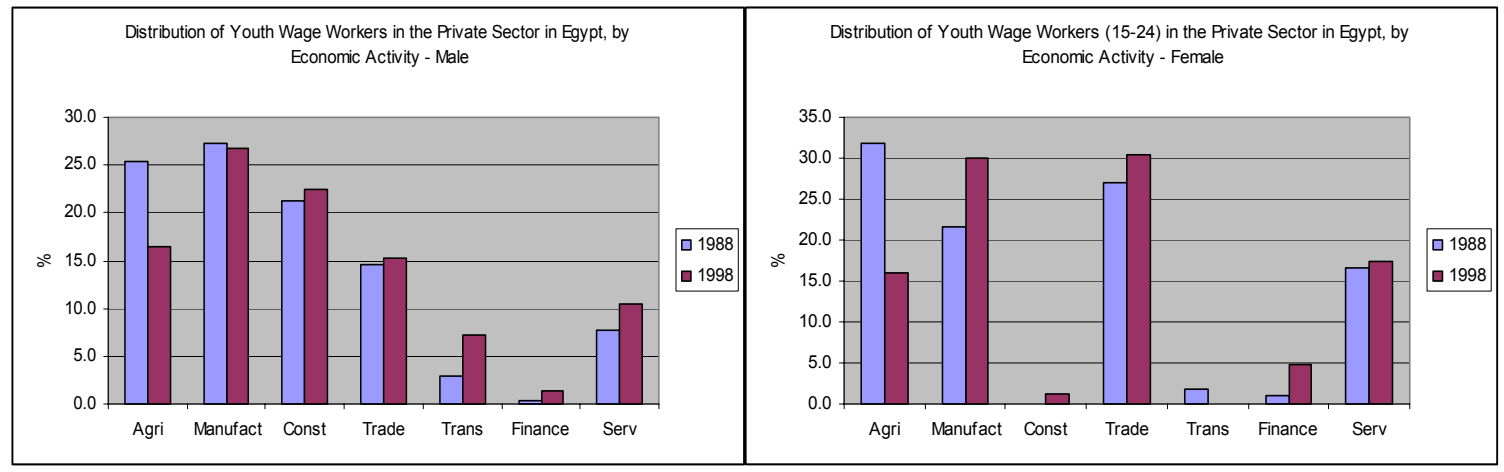

Source: LFSS, 1988, ELMS, 1998

Figure 6 shows the structure of economic activity for young men and women wage workers in the private sector in Egypt in 1988 and 1998. The figure shows male youth wage workers in the private sector are more evenly distributed among the various economic activities, while female youth are concentrated in agriculture, manufacturing, trade and 
services. The changes in the distribution of male youth among the various activities suggests some opportunities have emerged between 1988 and 1998 in transport and services and to a lesser extent in construction and trade. The leading activities - agriculture and manufacturing declined during the ten years, however, the decline in manufacturing was small and it remained as the leading activity in 1998. For female youth, opportunities for wage workers appear to have emerged in manufacturing, trade, finance and to some extent services and construction. The sharp decline in agriculture which was the leading private sector activity in 1998 resulted in making trade and manufacturing the leading activities followed by services. Finance appears to be a new area where opportunities are emerging for young women in the private sector. However, these emerging opportunities were not sufficient to offset the decline in agriculture, resulting in an overall drop in the proportion of female youth wage workers in the private sector.

Within the public sector, the government continues to offer opportunities for youth, mostly in services (see table A7 in appendix). It is interesting that the government continues to offer employment for young new entrants, despite a decade of economic reforms calling for public sector down-sizing.

\section{Changes in the Occupational Distribution of Youth Wage Workers}

As with the above section, this section will examine changes in the distribution of occupations among youth wage workers in the private sector and in the government, to observe emerging occupational opportunities. Table 12 shows the occupational distribution of youth wage workers in the private sector in 1988 and 1998.

Table 12 Distribution of Youth Aged 15 to 24 in the Private Sector in Egypt, by Occupation and Sex, 1988-1998

\begin{tabular}{|c|c|c|c|c|c|c|}
\hline & \multicolumn{3}{|c|}{1988} & \multicolumn{3}{|c|}{1998} \\
\hline & Male & Female & Total & Male & Female & Total \\
\hline Tech.\& Scientific & 2.8 & 11.6 & 4.3 & 3.8 & 14.4 & 5.1 \\
\hline Clerical & 1.2 & 11.6 & 3.1 & 1.2 & 12.9 & 2.6 \\
\hline Sales & 8.0 & 15.3 & 9.4 & 9.9 & 20.5 & 11.2 \\
\hline Services & 6.1 & 9.6 & 6.7 & 6.4 & 4.0 & 6.1 \\
\hline Agriculture & 27.6 & 31.4 & 28.2 & 16.2 & 16.1 & 16.3 \\
\hline Production & 54.3 & 20.6 & 48.3 & 62.5 & 32.1 & 58.7 \\
\hline Total & 100.0 & 100.0 & 100.0 & 100.0 & 100.0 & 100.0 \\
\hline $\mathrm{N}$ (weighted) & 530 & 114 & 644 & 564 & 80 & 644 \\
\hline
\end{tabular}

Clearly, the occupational distribution follows the same pattern as economic activity for youth in the private sector. In 1988, the leading occupations in the private sector for youth wage workers were production and agriculture. Despite the decline in agricultural activity among youth wage workers in the private sector, agriculture remained the second occupation for youth in 1998 - but more so for young men than young women. Sales was the second occupation for female youth wage workers in the private sector in 1998, where the share of female youth grew from 15.3 percent in 1988 to 20.5 percent in 1998 . The proportion of female youth in Technical and Scientific jobs such as nursing and teaching as well as in clerical, occupations also increased in the ten year period. Whereas the share of 
male youth in services increased modestly, the proportion of female youth in these occupations dropped by more than 50 percent between 1988 and 1998.

The occupational distribution of jobs in the government for youth only confirms the expansion in social services - namely technical and scientific jobs. There has also been a notable increase in clerical jobs (see Table A8 in the appendix). It is likely that the expansion efforts of social services, namely health and education, in the past decade, especially in Upper Egypt and in rural and remote areas offered work opportunities in the government for new entrants into the labor force.

\section{CONDITIONS OF WORK}

The previous section surveyed changes in the structure and distribution of work opportunities in the economy for young people. This section looks into the conditions of work and how they have changed over the past decade. Work conditions are analyzed through working hours, work stability, availability of contract, work in/out of establishments, incidence of social security benefits and medical insurance. It is expected that working condition in the public sector would be better than in the private sector, assuming better adherence to labor laws. Nevertheless, working conditions will be observed in both the public and private sector. As with the previous sections, gender differentials will be noted.

\section{Changes in Working Hours of Youth Wage Workers}

Table 13 shows the average working hours per week for youth wage workers by sector and sex in 1988 and 1998. Interestingly, average working hours for both male and female youth wage workers increased in every sector, including the government and state owned enterprises. In 1988, youth working in the government worked on average 36.6 hours per week -- less than the conventional 40 hours per week; in 1998, it increased to an average of 42.5 hours per week. Male youth in the government worked on average more hours per week than female youth - an average difference of 3.6 hours in 1988 and 6.2 hours in 1998. Average working hours in SOEs was over 40 hours per week in 1988 (47.7) and also male youth worked on average 6.3 hours more than female youth. In 1998, average working hours for youth working in SOEs increased to 51.1. While average working hours for male youth did not change, for female youth it increased by an average of 11 hours from 44.3 in 1988 to 55.2 in 1998.

Average working hours in private sector agricultural wage work increased modestly for young men between 1988 and 1998, however, for young women working hours increased dramatically from 39.6 in 1988 to 71.2 in 1998 - an average increase of 32 hours. While the increase in working hours for young women appears to be exaggerated in the data, interviews with young women working in private non-agriculture work shoe that their working hours ranged between 8 to 60 per week; working in non-agriculture period. Therefore, does not seem to be an exaggerated number for agriculture work in nonagricultural private sector wage work, working hours for youth increased an average of 4.7 hours between 1988 and 1998 - more for young men than for young women.

Table 13 Average Working Hours Per Week for Youth Wage Workers (Ages 15 to 24) in Egypt, by Sector and Sex, 1988-1998 


\begin{tabular}{|c|c|c|c|c|c|c|}
\hline & \multicolumn{3}{|c|}{1988} & \multicolumn{3}{|c|}{1998} \\
\hline & Male & Female & Total & Male & Female & Total \\
\hline Government & 38.8 & 35.2 & 36.6 & 45.5 & 39.3 & 42.5 \\
\hline SOE & 50.6 & 44.3 & 47.7 & 50.7 & 55.2 & 51.1 \\
\hline Private agric. wage work & 37.1 & 39.6 & 37.6 & 40.4 & 71.2 & 44.1 \\
\hline Private nonagric. wage work & 48.2 & 50.5 & 48.6 & 53.4 & 52.8 & 53.3 \\
\hline Total & & 43.2 & 44.6 & 50.7 & 49.3 & 50.5 \\
\hline
\end{tabular}

Source: LFSS, 1988, ELMS, 1998

\section{Changes in Work Stability for Youth Wage Workers}

Table 14 shows work stability for youth wage workers by sector and sex for 1988 and 1998. In general, most public sector work is permanent while most agricultural wage work in the private sector is casual. Between 1988 and 1998, there has been a significant increase in the proportion of youth wage workers in temporary employment in both the public sector and the non-agricultural private sector. The proportion of male youth working on a temporary basis in the government increased from 6.4 percent in 1988 to 11.6 percent in 1998, while for young women it more than doubled from 13.2 percent in 1988 to 31.9 percent in 1998. The proportion of female youth working permanently in the government dropped 18 percentage points from 86.8 percent in 1988 to 68.1 percent in 1998. Similarly, the proportion of young men and women in permanent employment in SOEs declined sharply. Thus, it seems that most of the new job opportunities in the government observed earlier for young women are temporary positions. It also appears to be that the government is proceeding gradually towards down-sizing the public sector by reducing opportunities for permanent employment for young new entrants. The proportion of young men and women wage workers in temporary employment also increased in the non-agricultural private sector during the decade - more for young women than young men. Permanent employment increased only among youth wage workers in the agricultural private sector.

Table 14 Work Stability of Youth Wage Workers (Ages 15 to 24) in Egypt, by Sector and Sex, 1988-1998

\begin{tabular}{lrr|rr|rr|rr|rr}
\hline & \multicolumn{2}{c|}{ Permanent } & \multicolumn{2}{c|}{ Temporary } & \multicolumn{2}{c|}{ Seasonal } & \multicolumn{2}{c|}{ Casual } & \multicolumn{2}{c}{ Total } \\
\cline { 2 - 12 } & 1988 & 1998 & 1988 & 1998 & 1988 & 1998 & 1988 & 1998 & 1988 & 1998 \\
\hline Male & & & & & & & & & & \\
Government & 90.0 & 88.2 & 6.4 & 11.8 & 0.0 & 0.0 & 3.6 & 0.0 & 100.0 & 100.0 \\
SOE & 93.5 & 68.0 & 6.5 & 32.0 & 0.0 & 0.0 & 0.0 & 0.0 & 100.1 & 100.0 \\
Private Agriculture & 16.0 & 19.1 & 0.0 & 1.4 & 0.2 & 4.8 & 83.8 & 74.7 & 100.1 & 100.0 \\
Private Non-agriculture & 55.7 & 55.1 & 9.7 & 15.7 & 0.9 & 0.5 & 33.7 & 28.7 & 100.1 & 100.0 \\
Total & 51.4 & 53.4 & 7.1 & 14.1 & 0.6 & 1.1 & 40.9 & 31.4 & 100.0 & 100.0 \\
Female & & & & & & & & & & \\
Government & 86.6 & 68.1 & 13.4 & 31.9 & 0.0 & 0.0 & 0.0 & 0.0 & 100.0 & 100.0 \\
SOE & 89.5 & 47.6 & 10.5 & 28.6 & 0.0 & 0.0 & 0.0 & 23.8 & 100.1 & 100.0 \\
Private Agriculture & 9.7 & 17.4 & 0.0 & 0.0 & 25.8 & 74.6 & 64.5 & 8.0 & 100.0 & 100.0 \\
Private Non-agriculture & 73.9 & 59.1 & 16.0 & 31.0 & 2.4 & 4.7 & 7.7 & 5.2 & 100.0 & 100.0 \\
Total & 68.5 & 58.5 & 11.6 & 28.4 & 5.5 & 9.4 & 14.4 & 3.8 & 100.0 & 100.1 \\
\hline
\end{tabular}

Source: LFSS, 1988, ELMS, 1998 


\section{Changes in Contractual Work}

An important indicator of job security and work formality is the existence of a contract between the employer and employee. Table 15 shows the availability of contracts among youth wage workers in the public and private sectors by sex for 1988 and 1998. As the table shows, a larger proportion of female youth wage workers have contracts than male youth. Between 1988 and 1998, the proportion of youth with contracts declined slightly for young men from 19.0 percent to 18.3 percent, but the drop was significant for young women from 50.4 percent in 1988 to 44.4 percent in 1998. Expectedly, most youth working in the public sector have legal work contracts. However, most youth working in the private sector do not have employment contracts. Between 1988 and 1998 the proportion of male youth in the public sector without contracts decreased while for female youth it increased - more for SOE workers than for government workers. The proportion of youth in non-agricultural private wage work without contracts increased for both young men and women during the 10 year period - but more for young women than for young men.

Table 15 Availability of a Contract for Youth Wage Workers (Ages 15 to 24) in Egypt, by Sector and Sex, 1988-1998

\begin{tabular}{|c|c|c|c|c|c|c|}
\hline & \multicolumn{3}{|c|}{1988} & \multicolumn{3}{|c|}{1998} \\
\hline & Yes & No & Total & Yes & No & Total \\
\hline \multicolumn{7}{|l|}{ Male } \\
\hline Government & 89.2 & 10.8 & 100.0 & 93.5 & 6.5 & 100.0 \\
\hline SOE & 79.6 & 20.4 & 100.0 & 89.8 & 10.2 & 100.0 \\
\hline Private Agriculture & 2.8 & 97.2 & 100.0 & 1.4 & 98.6 & 100.0 \\
\hline Private Non-agriculture & 12.2 & 87.9 & 100.0 & 8.0 & 92.0 & 100.0 \\
\hline Total & 19.0 & 81.0 & 100.0 & 18.2 & 81.8 & 100.0 \\
\hline \multicolumn{7}{|l|}{ Female } \\
\hline Government & 89.8 & 10.2 & 100.0 & 87.8 & 12.3 & 100.0 \\
\hline SOE & 85.8 & 14.2 & 100.0 & 47.6 & 52.4 & 100.0 \\
\hline Private Agriculture & 0.0 & 100.0 & 100.0 & 0.0 & 100.0 & 100.0 \\
\hline Private Non-agriculture & 25.7 & 74.3 & 100.0 & 17.9 & 82.1 & 100.0 \\
\hline Total & 50.2 & 49.8 & 100.0 & 44.4 & 55.6 & 100.0 \\
\hline
\end{tabular}

Source: LFSS, 1988, ELMS, 1998

\section{Changes in the Distribution of Youth Wage Workers In and Out of Establishments}

Wage work in the survey has been classified into in-establishment and out-ofestablishment. An establishment is defined as a fixed place dedicated to economic activity, outside the home. Coupled with other factors, working in establishments is sometimes used as an indicator of formal work. According to the definition above, all public sector work is considered to be in establishments while all agricultural work is outside establishments. Table 16 shows the distribution of youth wage workers in private sector non-agricultural work in and out of establishments. The majority of youth wage workers in the nonagricultural private sector work in establishments. Between 1988 and 1998 the proportion of youth working outside establishments dropped from 46.3 percent to 40.9 percent, respectively for male youth and from 22.5 percent to 12.2 percent for female youth. While this may indicate increased formality, the trends observed above in working hours and stability, rather suggest and increase in informal work. 
Table 16 Distribution of Youth Wage Workers (Ages 15 to 24) in the Non-agricultural Private Sector in Egypt, by Sex and In/ Out of Establishment, 1988-1998

\begin{tabular}{|c|c|c|c|c|c|c|}
\hline \multirow[b]{2}{*}{ Sex } & \multicolumn{3}{|c|}{1988} & \multicolumn{3}{|c|}{1998} \\
\hline & $\begin{array}{c}\text { In } \\
\text { establishment }\end{array}$ & $\begin{array}{c}\text { Outside } \\
\text { Establishment }\end{array}$ & Total & $\begin{array}{c}\text { In } \\
\text { establishment }\end{array}$ & $\begin{array}{c}\text { Outside } \\
\text { Establishment }\end{array}$ & Total \\
\hline Male & 62.5 & 37.5 & 100.0 & 61.7 & 38.3 & 100.0 \\
\hline Female & 87.2 & 12.8 & 100.0 & 94.3 & 5.7 & 100.0 \\
\hline Total & 66.2 & 33.8 & 100.0 & 65.8 & 34.2 & 100.0 \\
\hline
\end{tabular}

Source: LFSS, 1988, ELMS, 1998

\section{Changes in Social Security Coverage and Medical Insurance for Youth Wage Workers}

Social security coverage and medical insurance are considered basic benefits in employment and are used as indicators of working conditions. Due to unavailability of information on the coverage of social security and medical insurance for youth wage workers in the public sector in 1988, Table 17 shows social security coverage and medical insurance for youth in the private sector. Young men and women were less likely to have jobs with social security or medical insurance in 1998 than they were in 1988. Women were considerably more likely to have jobs with benefits than men. Among youth working in nonagricultural wage work over 80 percent neither have social security nor medical insurance. Between 1988 and 1998, there has been a small decrease in the proportion of youth with these benefits.

Table 17 Social Security Coverage and Medical Insurance for Youth Wage Workers (Ages 15 to 24) in the Private Nonagricultural Sector in Egypt, by Sex, 1988-1998

\begin{tabular}{|c|c|c|c|c|c|c|}
\hline & \multicolumn{3}{|c|}{1988} & \multicolumn{3}{|c|}{1998} \\
\hline & Yes & No & Total & Yes & No & Total \\
\hline \multicolumn{7}{|c|}{ Social Security } \\
\hline Male & 15.0 & 85.0 & 100.0 & 10.7 & 89.4 & 100.0 \\
\hline Female & 27.9 & 72.1 & 100.0 & 16.2 & 83.8 & 100.0 \\
\hline Total & 16.9 & 83.1 & 100.0 & 11.3 & 88.7 & 100.0 \\
\hline \multicolumn{7}{|c|}{ Medical Insurance } \\
\hline Male & 5.1 & 94.9 & 100.0 & 4.6 & 95.4 & 100.0 \\
\hline Female & 16.7 & 83.3 & 100.0 & 7.1 & 93.0 & 100.0 \\
\hline Total & 6.8 & 93.2 & 100.0 & 4.9 & 95.1 & 100.0 \\
\hline
\end{tabular}

Source: LFSS, 1988, ELMS, 1998

Overall, working conditions appear to have worsened during the decade for youth wage workers in Egypt with longer working hours, lesser stability and fewer benefits. These indicators may also suggest that the few opportunities which emerged in the labor market for youth wage workers are most likely in the informal sector. However, further analysis on these indicators and other measures of formality are necessary before making a statement in this regard. 


\section{CONCLUSION}

The above analysis tells a mixed story on young people's work opportunities in Egypt. To begin with the good news, more Egyptian youth are educated and tend to stay longer in school in 1998 than in 1988. Young women are entering the labor force earlier than their older sisters and staying longer while male youth are entering later than their older brothers and retiring earlier. Opportunities for wage work emerged in government, mainly in technical \& scientific and clerical jobs. There were also emerging opportunities in nonagricultural private sector activities, mainly manufacturing and trade.

But the good news stop here. Youth in Egypt carry the largest burden of unemployment. 1.3 million young men and women are able, ready and searching for work but are without employment. The number increases when the search criterion is relaxed reflecting a large number of young people who stopped searching and dropped out of the labor force. The situation is worse for young women whose unemployment rate is three times the rate of young men and more than twice the overall female unemployment rate. More than half of the young women in the labor force have intermediate and above education but are unemployed.

The proportion of youth wage workers increased modestly over the ten years. While the proportion of young men working for wages increased significantly, there was a sharp decline among young women. As young women were mostly concentrated in state owned enterprises and private sector agriculture - the two sectors which suffered sharp declines during the ten year period of economic reforms, their share dropped significantly in wage work. Opportunities in the government and in the private non-agricultural sector emerged for young men, especially in technical and scientific jobs, trade, services, construction and transport. The government also offered opportunities for young women and there were also a few emerging opportunities in manufacturing, trade and finance. However, growth in these areas was slower than the decline in SOEs and private agriculture, resulting in an overall drop in the proportion of wage workers in Egypt.

Working conditions also became less stable for youth, especially for young women. There are fewer permanent jobs, less contractual work, and in the few emerging opportunities, working hours were longer and work is temporary.

The results support the hypothesis that the formal private sector remains small and is not meeting the demands of the rapidly increasing and educated new entrants - Egypt's youth. The results also support the arguments that women bear the brunt of adjustment in times of economic reform, namely in fewer opportunities, greater work instability, fewer benefits and longer hours. These results need to be tested further before causality is established between the Economic Recovery and Structural Adjustment Program and the limited opportunities for youth in the labor market.

Although preliminary, these results have serious policy implications. Indeed it is not only important to address constraints on the demand for labor from a policy perspective, but 
also to tackle the specific issues which affect men and women differently. With a large young population and improvements in education and health care, youth in Egypt hold a great promise for the economic development of the country. Whether, youth translate into a 'window of opportunity' or an 'obstacle to growth' is very much a function of the commitment of all stakeholders and the incentives and policies of policy makers in Egypt. 


\title{
Chapter Four
}

\section{Opportunities and Work Conditions in the Private Sector}

\author{
Nagah Hassan Al-Bassusi
}

\section{INTRODUCTION}

This chapter explores the impact of national and international economic change in the last decade through an analysis of in-depth case studies of 27 young Egyptian women working in three sectors of the wage economy. To retain a focus on the effects on Egypt's ambitious structural adjustment program, young women who entered the workforce during this time were interviewed about their experience with the labor market.

Structural adjustment programs work on the premise that by letting free markets work and by promoting competitive conditions, worker productivity and welfare will improvethese involve fundamental changes in the economy as it moves to gain a competitive edge in the world economy. Labour markets are expected to adjust and respond to these changes. To capture the effect of such changes in the growing sectors of the economy, several of the cases were sampled from factories manufacturing garments for export, the sector widely assumed to be at the forefront of globalization. It is also expected that as a result of structural adjustment, younger, better educated women would take the place of older women in the workforce and perhaps even of men, given that many export oriented production sectors, such as the garment industry, usually employ young women. Yet our quantitative analysis finds the highest rates of unemployment are among the younger cohorts of women in the labor force. This is unusual for economies trying to develop through export oriented markets such as the garments sector. By exploring the cases of some young, female wage workers in depth, we hope to shed light on why high rates of unemployment have prevailed among their sisters.

As public sector enterprises shrank in size new female entrants resorted to sections of the private sector for employment. There were some opportunities created by an exportled growth strategy and trade liberalisation which encouraged multinational corporations to relocate production facilities and subcontract parts of production processes to many lowwage countries. A growth in the number and size of export-oriented manufacturing facilities, whether built by local or foreign investors, have resulted in an increase of the participation of women - and particularly of young women - in private sector employment.

This study contributes to a growing literature and responds to interest in the impact of such globalizing trends on the lives of young women. In general, young women are often the 
preferred employees for jobs in sectors like garment manufacturing and sales. Standing (1989) argues that the adoption of flexible labour practices and supply side development strategies (structural adjustment policies) led to an increase of women's economic roles (i.e., their participation in labour force is increased), but also to a weakening of their income and employment security. Labour market regulations are eroding and regarded as unnecessary costs and rigidities. Others argue that young women are better off as employees in the private sector than at home or in the public sector. Their exposure to modern life, modern dress and salaries that are higher than the ones paid in government service all help to raise these young women's aspiration and self-esteem reference (Kabeer, 1991; Amin et al, 1997).

This paper explores the situation of young female entrants into Egypt's labour market within this new economic environment to better understands the range of options and work roles available to young women across various sectors within the formal private sector. Through description of work conditions, the paper provides an assessment of gaps and felt needs from the perspective of workers, and accordingly, provides broad guidance for policy and programmatic interventions. It is organized as follows: the first section describes the study method and data. Section two reflects on what the sampled cases for the qualitative study may be reasonably assumed to represent by analysing their characteristics compared to the profile of wage workers revealed by the 1998 Egypt Labor Force Survey. The discussion of the survey data helped to place the results from this small scale in-depth study in a larger context. The third section of the paper draws on the experiences of individual young women wage workers included in the study. Together, the quantitative and qualitative analyses sketch out the experience of these relatively recent entrants' work conditions and provides the basis for recommending actions that aim to improve the access to and conditions of work for young female labour market entrants.

\section{SECTION I: DATA AND METHOD}

To further explore young women's livelihood opportunities the Population Council also conducted an in-depth qualitative study on youth livelihood opportunities to investigate changes in opportunities as a consequence of the economic transformation process, to identify emerging sectors for young women's employment, and to learn about the working conditions in the leading sections of the private sector. This chapter presents results from the case studies of young, female wage workers.

The case studies were conducted through a series of in-depth interviews conducted over the course of over a year and multiple visits to the respondent's households. These interviews were transcribed and translated and summarized into case histories for analysis by the research team. The study focuses on working girls in the private sector in three different parts of the Egyptian Delta. The surveyed respondents came from three occupational sectors: Garment manufacturing sector in an industrial zone (7 cases), sales and services sectors in an urban area near Cairo (11 cases), and small factories in Mansura city, Dakahlia governorate (10 cases). Girls working in garment, sales and services sectors were all urban, and those sampled in Mansoura factories live in a rural village near Mansoura.

Data collection for the in-depth study took a case study approach for each of the sampled workers. Interviews were conducted with the worker, her family members and her 
peers at work. To the extent possible, representation within a particular occupational category was ensured by adopted a random selection process appropriate and feasible for the chosen study sites. The selection process in the industrial zone came closest to a true random selection enabled by the fact that the authorities of the zone maintained a fairly complete listing of all workers who have worked in any of the factories in the recent past. Thus, we were able to randomly select cases from this roster. In the Greater Cairo location, the study used a complete listing of households provided by an NGO working in a public housing area. This household listing enabled the selection of households at random which were then contacted to locate adolescent girls who were engaged in wage work. This was done by administering a brief questionnaire. The sample selection process in Mansoura elicited the help of another NGO working to provide micro-credit services to young girls and women. Their roster of eligible girls and women provided a frame from which girls engaged in wage work were selected. While the selection process is by no means completely random, it was designed to prevent self-selection of more articulate respondents which would bias the profiles. The total number of interviews conducted in each site was influenced by the authors assessment as to whether additional interviews were yielding new information,

The interviews were open ended but elicited responses on young women's working conditions, their work experience, and their search for job opportunities as well as a host of personal and family background information. In addition to an analysis of the in-depth interviews, this paper analyses the New Labour Code and Social Security Code to explore the gap between granted legal rights and actual practice. While the macro-level survey data and the two legal codes identifies the gaps between granted labour rights and real practices, the qualitative analysis tries to explain the causes of these gaps.

\section{Section II: Characteristics of the Sample and What It Represents}

The focus of the study is on early work experience. The sampled women for the qualitative study ranged in age from 15 to 29 years. Some older women who were sampled were kept in the survey for retrospective information. The research design assumes that in order to learn about experience with the workforce as well as information about marriage and schooling related to work, it is useful to have a combination of women who have recently completed the process as well as younger women who are going through the process. The particular focus of the in-depth study is on female wage workers in the non-agricultural sector as that is the sector generally expected to be in the forefront of Egypt's development in the future.

\section{Section III: Worker Perspectives}

This section explores the narratives of workers and working conditions of young women in production, sales and services. Survey data on contracts and working hours report on the gaps between labour rights and labour practices, while an analysis of in-depth interviews explains the existence of these gaps, and attempts to better explain how girls think

of their work conditions. The section concludes with a summing up in terms of the relative bargaining position of workers.

Overall the narratives of workers suggest that while they recognize the exploitative nature of their terms of employment, they also believe that the private sector holds the most 
promise for delivering jobs to new, poorly qualified workers like them. Some of our respondents were colourful in their expression of their situations:

"Staying at home is boring and oppressive. But working in the field of investment is health consuming .... I am calling " istesmar" (investment) "isteimar" (colonialism)." Amera, 19 year old, commercial high school, industrial zone. for them:

Others are more pragmatic in their assessment of what policies hold the most promise

"Many thanks to employers. They have found us millions of job opportunities. They pay taxes, electricity, and salaries - and still need to make a profit. How can they do that if they don't exploit us in one way or another? I believe that the solution should come from the government, from the parliament, or from the Shoura' council. Investors should be treated well - so that they, in turn, are able to adhere to laws related to workers 'rights." Hoda, commercial high school, 26 years old, industrial zone.

Contrasting the reactions of workers with differing salary levels, it appears that a worker's assessment of her work condition appears to be more a reflection of the employer/ employee relation and the treatment of workers by their employers, than it is a reflection of the level of remuneration for their work. Amera works in one of the most modern and (financially) rewarding sectors of the economy, in a well- appointed garment factory. She earns a substantial salary. For Amera, at issue are the long working hours, mandatory overtime work, and lack of flexibility in terms of ability to leave for another job. Thus, although garment work pays high wages, the work conditions lead Amera to the realization that she is being exploited and therefore that the sector is perpetuating a system similar to "Isteimar" or colonialism..

Workers seem to recognize that there has been a large scale withdrawal of the state from its historic role of granting guaranteed job opportunity, and regard the modern private sector as the main source for new jobs as reflected by Hoda in the second quote. Their attitude towards their jobs and their employers appears to be most influenced by the lack of alternatives, by the difficulties that most experience in finding a job in the first place, and by a continuing awareness that despite all of the hardships they face, they are fortunate to have a job. The response to the hardship instead is to have limited expectations about these jobs. For various reasons related to the experience of work and to their social circumstances, workers accept these extreme hardships with the expectation that they have to be endured only briefly until they are able to save enough money to leave the workforce and settle into marriage.

\section{Labour Market Entry: The Job Search Process}

The context of high unemployment all around is an important determinants of worker attitudes. In general, Egypt's youth carry the largest burden of unemployment. They constitute almost two thirds (63.7\%) of the unemployed persons in the labour force in Egypt. At an open unemployment rate of 30.7 percent, youth unemployment is almost three times the overall unemployment rate in Egypt (11.7). That is, 4.1 million young men and women 
who are able, ready, and searching for work are without employment (See Chapter 3). These indicators highlight the inability of the economy to create enough job opportunity, and accordingly, available jobs, including the unskilled ones which are highly competitive for youth.

The situation for young women is much worse than their older sisters and male peers . The open unemployment rate for young women is 59.4 percent- over three times of rate of young men (19) and more that twice of the overall female unemployment rate (27.6). That is, more than half the young women in the labour force are unemployed and seeking employment. The highest rate of unemployment is among women with intermediate $(75.9 \%)$ and secondary $(69.3 \%)$ level education (See Chapter 3 ). As such our sample of young women who have had some experience in the workforce in the past or are currently working, represents a group that has been luckier than most of their counterparts. However, the job search process was difficult and rank high among the hardships that they have endured in their young lives.

Question: How did you find your job?

Mona: $\quad$ "It is very embarrassing to search for a job. Fifteen days after I finished my exams, I decided to work to help myself. I went and looked at shops to see if there are any vacancy announcements. ${ }^{14}$ Whenever I saw such an announcement, I would go into the shop and ask. I did that many times and the answers have been frustrating: they always ask you to leave your phone number and promise to call you later and they never call, or they claim the owner is not in at the moment, and ask you to come again later. Once I entered a shop and asked about a vacancy. They told me we have already hired a girl. I reminded them of the announcement that was posted outside. 'No, the vacancy was no longer there, they said, and they would get the announcement off right away'. I kept unsuccessfully trying until my friend helped me to find the job I am in now. She stipulated to her employer either to hire me or she will leave his shop. He had to accept because he was in need for her. It is very embarrassing-"

\section{Mona, 20 year old, Commercial high school. Currently working in clothes shop.}

Mona highlights the difficulty for poor young women who do not have much education, have little to offer by way of specific skills or expertise, and have few institutions or avenues to resort to for finding a job appropriate for their skill level. Despite being ready to accept long working hours and other work hazards, young women feel that the search process for a job opportunity is difficult and embarrassing. For most of our respondents who did not have a relative or a friend already working in a place that was looking for other workers, finding work is essentially a test of endurance and perseverance. They have no skills so they have to try for a range of low level jobs in factories, shops or other service sectors. Since there is no way other than to look through face to face interaction, this process necessarily entails being rejected which has considerable personal cost, since Such rejection is considered a personal affront and is embarrassing.

\footnotetext{
${ }^{14}$ Usually, clothes shops hang an advertisement at the main door of shop when they are looking for an employee.
} 
Mona's experience appears to be typical of the experience of working girls in Cairo and is different from the experience of the respondents in the industrial zone or the rural area. It may be a function of the relative absence of functioning social networks there. As such her experience highlights the significance of social networks in the job-search process. Social networks seem to be stronger in the rural site we studied. In general, rural workers also appeared less likely to voice frustration and were more likely to praise and be thankful for their social support system and their connections. Our case studies suggest that there, for girls it was simply a matter of expressing a desire to work, and her family members, neighbours, or relatives would join forces to find her the right job. When a working girl finds a job for her female friend, the latter's family has to check the safety of work place before sending their girl to work. Most parents of working girls have visited their daughter's work place and are known by their employers.

Respondents from the industrial zone also express less frustration and embarrassment about finding work compared to the girls of Cairo. We speculate that this is because the factories are close to each other (all factories in the industrial zone are located within a secured compound) and social networks have developed among the workers. Also, the city that the zone is located in is small and there appears to be a shortage of labour. Several factories have resorted to providing transport facilities from nearby cities and villages to enhance their pool of workers. More importantly from the worker's perspective perhaps is that because of the presence of peer networks, it is easy for new entrants to find out about availability and about the nature of work in the industrial zone. Even though it may still be a matter of knocking on a factory's door and asking for any positions available, social networks help by guiding new entrants to places where work is available.

The importance of networks in the Egyptian context has been highlighted by public debates and discussion on the system of "Wasta" or patronage in finding work. Some of the non-working peers who were interviewed in the process of preparing our case studies of wage workers complained that the reason they did not have a job was because they did not have "Wasta", that is they do not have access to the developing patronage system.

\section{MOTIVATION FOR WORK AND THE QUALITY OF JOBS}

The in-depth interviews attempted to elicit what led the individual respondents to work and by what criteria potential and existing jobs were assessed by the workers themselves. Our respondents generally appear to be self-driven in terms of their motivation to work. For this generation of workers the ability to leave the house, to find a role for themselves beyond the traditionally prescribed role of wife or mother, to be able to engage in a wider network of peers beyond family and neighbors, were important reasons for wanting

to work. Such attitudes are common for cohorts of labor market entrants who are the first generation of workers. The novelty of working outside the home and the exposure to a wider world is often an important reason. When asked why she went to work initially, our rural respondent, Sharmeen, said she wanted to go to be like all the other girls in the village, to learn and to make friends. Sharmeen also said she preferred to work in a factory than working at home because even though factory work entailed long hours, she liked the fact that she got to go out. Sharmeen is young and her motivations were also very straight 
forward. Another worker, Sayeeda, mentioned more complex emotions. She liked to work because she liked the freedom and autonomy it gave her. Another worker, Samia said she went to work to help her father prepare her for marriage. According to the mother of three workers in the investment zone, the daughters went to work right after their graduation, and unlike other girls who spent their earnings on specific items for their "gehez" the daughters "invested" their money into their family home. The mother offered the opinion that this investment was necessary also in preparation for their marriage to portray a positive family image. Most girls stated that they themselves decided that they would look for work. Although some respondents did indicate that they were compelled to work because of their poverty, none expressed to us any sign that they were forced by family members to work. At most there were descriptions of parents or other family members as benevolent benefactors who helped girls to find their ways to jobs. ${ }^{15}$

Thus, when respondents were asked directly about reasons why they sought to work in the first place, the responses ranged from reasons such as economic necessity, need for companionship, using up spare time, a way to legitimise going out (of the house) and accumulation of money for marriage. Indeed, saving for marriage appears to be a major preoccupation for single workers. In general, marriage is an important concern for the workers themselves and for their families, as it is for most girls of this age in Egypt. For working girls, it appears that, rather than being an alternative to marriage, work is viewed as a step towards a better marriage. Earning money is an important if not the only means towards that end. Work affects marriage directly through saving for marriage preparations, but also indirectly by allowing girls to meet more potential partners. ${ }^{16}$

The average monthly income for a regular female worker aged 15-24 years in the private sector is $115.00 \mathrm{LE}$ (See Chapter 3). This average is approximately equal to the average monthly income of a newly recruited person with intermediate level education in the public sector. It is not a living wage to support a family and most married men who have such public sector jobs will find a second job in order to make ends meet. This level of income would also be inadequate for a single male who is thinking about marriage preparation.

However, for women the evaluation of this salary is different. When asked about the adequacy of salaries, women are eager to portray the culturally appropriate image that their earnings are not essential for their survival, that their families are not dependent on their income and therefore, any positive earnings are considered adequate and worth the time and effort. This is possibly attributable to a strong culturally constructed ideals that women are in no way financially responsible for family livelihoods, and portraying them as such would be an affront to the prestige of their men folk. This is even true for women who are de facto heads of households. Rather, we found that other work conditions were repeatedly brought up as the primary criteria for evaluating jobs. These attitudes are summarized by Amera who says about her job "Any salary is better than nothing. Work is not all about money, ...The

\footnotetext{
${ }^{15}$ Equating personal interest with the household's collecting interest was also noted in a study of garment workers in Bangladesh (Amin et al., 1997).

${ }^{16}$ It is common for this generation of girls in Egypt to get to know a potential marriage partner and to give some importance to interpersonal attraction and compatibility and sometimes even to mention love.
} 
most important thing is to feel psychologically comfortable at the work place: to be treated well, respected and not exploited." Amera, 19 year old, commercial high school, industrial zone.

Amera reflects on three work conditions that are essential: by psychological comfort she implied freedom from sexual harassment on the work floor. When elaborating on good treatment she talked about insolent and aggressive manner of supervision, and exploitation referred to length of working hours in relation to salary. These aspects of work condition were raised as dimensions by which quality of jobs are judged regardless of sector of work or the sites studied.

Among the girls we interviewed, salaries varied according to the region, the sector of work and the girls' work tasks. Salaries in the investment zone were the best, ranging between 150 pounds for a helper (who trims excess thread from clothes, for example) to 500 pounds for an experienced girl who can operate a knitting machine. The majority of the study cases earned a salary above $250 \mathrm{LE}$. It is our judgement based on the worker narratives that while the pay is good, working on the lines in the industrial zone is hard work. the work is physically demanding and taxing compared to the kind of work done in small factories, sales, and services sectors. However, there the work is easier but the monthly salaries rarely exceed 100 LE.

The sales and service sector is arguably the most undesirable sector of work because of the long hours demanded in this sector. It also happens to be the sector with the best demonstrated potential for creating new job opportunities nationwide. For many girls, the income earned does not compensate for the long hours and dangerous working conditions. Work in shops often entails tasks that young workers consider degrading (e.g., sweeping the floor, cleaning the of work place). The potential for exposure to sexual harassment is also a concern since girls are often by themselves in these shops and do not have the safety in numbers that factory work affords. Girls often opt for lower pay to avoid these downsides of sales and service sector jobs. Avoiding the risk of sexual harassment is probably the single most important determinant in choosing work. The probability of exposure to sexual harassment is considered to be highest in services sector, less so in sales, and negligible in the large open factory spaces of the garment industry. Garment factories provide a relatively safe environment since a large number of workers are present in the same space and can collectively provide tight social control. In the service sector and to a lesser extent in small factories the risk of harassment by employers or customers is higher. Similarly, public transportations are relatively risky.

The typical response to sexual harassment is to quit work rather than confront or challenge the perpetrator. "I worked in a private infant baby clinic. My task was to clean the clinic, and to look after the babies and change their diapers. My salary was 150 pounds per month. It was good because I didn't have to pay much for transportation. The problem arose when the doctor tried to harass me several times. I managed to handle it, until, one day, he made sure there were no other people in the clinic. He almost literally tried to rape me. I pushed him back and ran out of the clinic. I never returned to the clinic after this incident." Samia, 20 year old, high institute degree, urban site near Cairo 
To summarize, the risk of sexual harassment as a threat of violence or as a threat to reputation is probably the single most important criteria on by which a potential job is assessed. Work conditions in terms of working hours or treatment by supervisors come next. Salaries rank after these considerations. Other niceties of work such as contracts, social insurance and medical insurance, did not appear on the "radar screen" of the workers who were interviewed for this study.

\section{WORK CONTRACTS}

The new Labour code, Article 30 says "Contract of services must be in writing, drawn up in Arabic in three copies, one copy for each of the two parties, the third for the social insurance concerned office".

Having a work contract is in itself a right for each individual worker as indicated by labour law. It formalises the relation between its two parties (employer and employee) and states the terms of reference. Work contracts entitle the worker to social and health insurance. Length of working hours, the right for to a safe working environment, and other work rights are regulated by labour law. Bypassing work contract undermines the labour rights stated by law, and allows the employer to avoid facing retribution for violating labour rights by simply denying the relation.

Meanwhile knowledge about labour laws and the guarantees afforded by law is very limited among the young workers interviewed for the study. Labor contracts, although mandated by law, were never common in Egypt and have seen an even further decline in the past decade. Evidence from qualitative analysis also confirms that most employers do not offer contracts. All of the women we interviewed worked without a contract at the time of the interview. We explored the laws to understand why contracts are not more commonly in use. Employers believe that contracts are costly as they oblige employers to grant workers maternity and annual leave, sick leave, disability leave old age and disability and unemployment benefits. In addition, contracts limit the possibilities to dismiss employees. The article (61) of the New Labour Law states that: "Dismissal of a worker is forbidden unless he is guilty of heavy default" (New Labour Law: article 61). Proving 'heavy default' is a painstaking exercise, involving a committee composed of the director of the labour governorate of manpower, a trade union representative, and the employer or his representative (ibid: article 62, 63). These various obligations make employers reluctant to formalise work contracts.

For different reasons, many young women share the employers' preference for informality. Many believe (erroneously) that contracts commit them for a long term because when contracts are offered they stipulate long years of commitment to one workplace. Thus contracts are believed to restrict job mobility. In fact, it appears that employers only offer contracts that stipulate several years of work and a fine in case the contract is not fulfilled. Since most workers believe that they are not going to continue work after marriage they are hesitant to commit to contracts and have refused contracts even when they have been offered. 
Hind: I I don't have a work contract, and I wouldn't like to have one. It is a monopoly contract.

Question: What do you mean by a 'monopoly contract'?

Hind: If I want to work as a tailor, and I got trained inside the factory, I have to sign a contract to work for this factory for at least six years. If I didn't like the work and wanted to leave, I would have to pay the employer a 6000 LE penalty.

\section{Hind, 19 year old, commercial high school, industrial zone.}

\section{SOCIAL INSURANCE}

"All workers in the public and private sector are entitled to five types of insurance: senescence, disability and death; occupational accidents; health insurance; unemployment insurance; and social welfare for retired people" (Article One of the Social Insurance Law)

Workers are entitled to social insurance automatically by informing the Administration Authority of Social Insurance (Public Institution of Social Insurance). The New Labour Code and the Social Insurance Code oblige employers and employees to carry out the responsibility of informing this administration authority by sending them a copy of the work contract. "Contract of services must be in writing, drawn up in Arabic in three copies, one copy for each of the two parties, the third for the social insurance concerned office" (New Labour Code, article 30). Ministerial Decree No. 55 of year 1986 obliged the worker to inform the competent authority of any new job within a week of starting it.

According to the social insurance law, a worker is responsible for $14 \%$ of the salary to be saved in his/her social insurance account and employer is responsible for the equivalent of $26 \%$ of a worker's salary. However the penalty that employers have to pay for not contributing to a worker's social insurance is minimal compared to the costs of insuring: non-compliance to social insurance laws carried a penalty of only 10 to $50 \mathrm{LE}$ per worker. An elaborate system is in place to ensure compliance to the laws. Official inspectors visit work places to ensure registration of all workers for social insurance . Inspectors are required to report any employer found to be in violation of the laws. Nonetheless, it is more cost effective for them to pay the penalty since this costs the employer less than paying $26 \%$ of a worker's salary to social insurance. Evidence suggests that two approaches are adopted, varying to the situation and conditions.

Of the workers in the three sectors under study in this research, garment sector workers proved to be the most knowledgeable in this respect, but even in this sector only a small minority of the female workers seem to be covered. For young women, social insurance means foregoing current income for future insurance that they do not perceive a need for. Since social insurance requires a 14 percent contribution of the worker's salary to be paid directly to the social insurance office young female workers, who tend to stop working after or even a little before marriage, consider participating in the social insurance system a cost rather than a benefit. We learned from garment workers that the law accommodates girls who stop working when they get married, by enabling them to cash their balance once they have a marriage contract and promise to never work again. Even the girls who know about this arrangement may not find it an attractive one, as many girls stop 
working immediately after finishing the marriage preparations (and before they actually get married), and they would not be able to cash their balance.

Most of our respondents view social security as a pension after retirement, and assume that social insurance is a right for government and public sector employees only. Social insurance laws are not widely perceived to be applicable to the private sector as well as the public sector. In small concerns, pseudo-kinship relation often appear to take the place of more formalized insurance mechanisms. The security offered by social insurance may appear remote and inconsequential in comparison to the more familiar and immediate assurances offered by these kin-like ties that are often fostered between a worker and her employer. A worker like Manal, who never had social insurance, and worked in an auto parts shop for a long time, describes her employer in the following way: "Haj Said honoured us by visiting us in Ramadan and had breakfast with us. When I got married, he paid for the coiffure from his pocket money. He is like my father." With such a relationship at stake, it is unlikely that a worker like Manal would ever jeopardize this kind of trust by asking her employer for social insurance, which he would probably be hesitant to pay in any case.

\section{WORKING HoURS}

"No worker may effectively be employed more than eight hours a day or 48 hours a week excluding rest and meals interval" "The employer shall (...) grant the worker an additional wage equivalent to his full wage entitlement in respect of the overtime plus a minimum of $25 \%$ for hours worked in daytime and minimum of 50\% for hours worked at night." New labour law, article 133, and article 140.

The respondents in the qualitative survey claim that the average number of working hours per day is 10 (the minimum was 8 and the maximum was 12 hours per day). During peak periods, some girls work around the clock or more. Girls working in fashion shops normally start working at 8 a.m. and finish 12 hours later. During peak seasons these girls work until 11 p.m. Girls working in the investment zone officially start their work at 8.30 a.m. and finish it at 4 p.m., though in reality they start half an hour earlier and finish after 5 p.m. Occasionally, in times of large production orders, these girls have to work until as late as 11 p.m. Both the interviews and the survey data confirm that girls are rarely paid for overtime work they have to do.

While workers are willing to continue working such hours while they are working, the assumption that working in the private sectors necessarily entails such long hours has severe implications for their career aspirations. We did not find any exception to the rule that single workers intended to quit working after marriage. However, all of the respondent did say that they would continue work if an opportunity came up in the public sector. Public sector jobs are considered more compatible with marriage and with women's domestic roles primarily because of the considerably shorter working hours. Respondents described at least two other ways in which long working hours were undesirable: long hours are considered health consuming and they affect the reputation of girls by requiring them to be on the road after hours. 
The impact of long working hours on health is mediated by the nature of the work that the worker is engaged in. Below we give a brief description of the extent of variation in tasks among our respondents. In the garment sector, workers are allowed a one one-hour break in the middle of the day to have a meal that each girl prepares or buys for herself. This hour is not perceived to give adequate rest. All garment workers interviewed complained of fatigue. Operating a knitting machine (sitting) for long periods as well inspecting or finishing tasks (standing) are considered exhausting and workers describe ergonomic stress that would be predicted by the occupational epidemiology of this sector. There is not much evidence of awareness of the effects of such ergonomic stress on the workers or the steps that can be taken to alleviate such stress, although those who go through it are clearly suffering. In Amera's words : "I have to do my work standing on my feet all day long. The production is too much. The line produces 1200 pieces a day. All pieces have to be inspected the same day. I am the one who does this inspection. Some times the work exceeds my ability". Amera, 19 year old, commercial high school. Industrial zone.

Several of the girls complained of back pain. Some amount of psychological stress is generated by concern about the physical symptoms and what they represent. One worker expressed worries regarding her fertility. "Someone told me that back pain causes infertility. Some cases have been proven by doctors." Samah, 20 years old, commercial high school, Industrial zone.

Girls interviewed (and particularly the ones in the investment zone) express their frustration with the employers' insensitivity to their health complaints. Without medical insurance to resort to, employers seldom pay for medical treatment costs. Fatigue, considered an occupational accident in ministerial decree no 74 of 1998, is merely considered an indication of laziness by employers. Accordingly, girls are rarely allowed any sick leave, although sick and annual leaves are among the labour rights regulated by law. If a girl feels exhausted and takes a day off, employers cut her salary by three days as an absentee penalty. Overtime pay is rarely paid but absentee penalties seem to be enforced regardless of the sector of work

In the service sector (e.g., clinics, coiffures, supermarkets) and in small factories work hours are longer than in the production sector, but the workload seems lighter. In this sector, girls usually have to stay at work from 8.30 in the morning up to 12.00 midnight. However, many of these hours may be spent waiting for a customer, for instance. In the service sector, the number of clients determines the amount of work in a day, which is usually moderate. Respondents working in small factories indicated that the production process was less demanding and less intense than it is in the garment export oriented zones. Accordingly, the workload is less.

The respondents consider long hours in and of themselves less intolerable than their social consequences. Returning home late in the evening harms the girls' reputations, which, in turn, has an impact on their self-esteem and confidence. Amaal, a girl from the urban site near Cairo, works in a bakery. She can cope with the transport cost and time, and stands the high temperature in her work place. Even the long working hours (Amaal comes back home 
at 10 p.m.) were not in themselves a problem - until she learned about her neighbours' criticism.

"We used to gossip behind other people's back. I never thought that I might be a topic of gossip myself. But I am. When we come back late at 11 p.m., you can see the people looking at us wondering where we are coming from. Some times we ask our brother to meet us at the underground station and accompany us into the area on our way back home. By accompanying us, people see that our family knows where we are coming from." With a voice full of sadness Amaal continued:

"People don't think of the hard work we do. They only think of the time we come home. We cannot stop their gossip, but we won't stop working. If we stop working, there will be no salary!” Amaal, 20 year old, Institute of Electronics degree. Working in a bakery

Criticism mentioned by Amaal and many of the girls interviewed reflect the local society's lack of knowledge of the nature and obligations of work in the modern private sector. Although there has been much progress in accepting girls' work in modern sectors, people in traditional areas are hesitant to accept, or understand, the consequences of such work. Lack of awareness of the nature of work in modern sectors make girls' neighbours think badly of their coming late. The perception of this social disapproval of late hours was a matter of great concern to all girls interviewed.

\section{Factors Contributing to a Weaker Bargaining Position for Workers}

The in-depth case studies offer some insight into several processes by which worker's bargaining position is weakened vis-à-vis their employers. First, while these young women have all entered the workforce to earn wages, they do not view wages as a reflection of the value of their work. Rather work is valued for a range of other social and psychological factors. This allows employers to take advantage and to set arbitrary wage standards leading to exploitative terms. We speculate that efforts to develop more professional standards in the workplace would help to put workers perception of their own worth in perspective and would allow for a better valuation of their work in terms of wages.

Young female workers are strongly motivated to save for their marriage. For this reason they commit themselves to savings groups and other mechanisms through which they are quickly tied to large financial commitments. For instance, young workers are expected to dress well and that commits them to large clothing expense. Some employment entails considerable travel costs. But most importantly, the need to make regular monthly payments towards their dowry (or gehez) reduces their flexibility. Thus they would rather keep working for poor wages than take time off to acquire new skills. These early financial commitments may thus be a second factor working towards weakening their bargaining position.

In our study we observed different ways in which employers in varied sectors exercise monopoly powers or other means to strength their own position vis-à-vis workers. In Cairo and Mansoura districts, where most job opportunities are to be found in the service sector and small workshops, from the worker's perspective the search for a job is difficult. 
New entrants looking for vacancy announcements posted on shops are faced by the frustrations and embarrassment mentioned. The lucky few who are employed, feel gratitude towards their networks for introducing them to their employers. Aware of the fierce competition for jobs opportunities they will accept long working hours, the absence of insurance and other legal entitlements, and any salary offered.

In the export processing zone, where the overall shortage of workers should have placed girls in a good bargaining position, employers have been able to organize themselves together to restrict labor mobility and weaken the bargaining position of workers. Workers are issued contracts which require paying a penalty of 6000 L.E. if a worker leaves before completing the terms of the contract. In addition, a collective arrangement to control the movement of labour who work without contract has been established, known as the NoObjection certificate. When a worker wants to leave a factory for another job opportunity in another factory (s)he has to hold a No-Objection paper from his/her past employer. The NoObjection paper states that the employer has no-objection to the holder of the paper working for any other factory.

The system works on the basis of a gentleman's agreement among the investors to never accept a worker coming from another factory without the No-Objection paper. The agreement is enforced by the general manager of the Investment Association and also requires that any new entrant has to be registered at the Labour office in the Association, without which, he cannot enter any factory.

\section{CONCLUSION}

This paper supports Standing's claim that labour rights are widely ignored in the modern private sector in Egypt. The paper also shows that female labour market entrants tend to accept harsh working conditions at least for the relatively short durations that they envision working in the private sector. While these conditions are endured for work before marriage, they are also the reason why working in the private sector is considered unsuitable in the long run and incompatible with women's roles as wives and mothers. As a consequence, they feel little incentive to improve their professional skills that would allow them to continue working.

There are considerable and numerous barriers to accessing jobs that come with the guarantees as prescribed by labor laws. Foremost is that the knowledge of these rights among new entrants is practically non-existent. The language of the laws is such that they are not readily comprehensible to the lay person Even if a potential job seeker were armed with the knowledge of these guarantees under law, any individual worker's bargaining position is weakened by the fact that unemployment is high and there is severe competition for the few opportunities that are available. Most workers feel they need to earn to save for their marriage and faced with rising marriage costs and the perception that their marriage prospects decrease with age, motivates most girls to accept whatever work is available regardless of the level of hardship it entails. In some cases, such as in the industrial zones, employers have organized themselves to deliberately control the mobility of workers. 
Having stated all of the above, it should be noted that the benefits of work apparently outweigh the hard working condition, for at least a period of time. Our qualitative analyses shows some of the reasons why young girls value the opportunities they have. In their own view, their social and economic positions are considerably enhanced by working outside the home for wages. Notwithstanding social pressure, lack of social insurance, long working hours, exposure to sexual harassment, and a range of other hazards, many young women choose to work. They spend their money on personal and family expenses, and on their upcoming marriage. Although appreciative and proud of the personal characteristics they gain from work experience, few women (and none in our research group) are willing to continue working under the prevailing conditions after their marriage.

The right to social security insurance is rarely granted. This does not bother young women, who tend to regard such insurance more as a cost than as a benefit. Legal awareness, in combination with more serious penalties for employers found in default, could help to expand the coverage of social insurance. For this purpose, simplified versions of legislation need to be developed, as laws (and particularly the Social Insurance Code) are notoriously difficult to comprehend even for the well-educated. NGOs could fill this gap. NGOs are also called upon to connect young women with weak social networks to the labour market, and to create awareness among traditional communities on the demands work poses on female workers in the modern sector in an attempt to neutralise negative value judgements of the communities the working girls come from. 


\section{Appendix Tables}

Table A1. Distribution of Youth Population (ages 15 to 24) in Egypt, by Urban/Rural Residence, 1988-1998

\begin{tabular}{|c|c|c|c|c|c|c|c|c|c|c|c|c|}
\hline & \multicolumn{4}{|c|}{ Urban } & \multicolumn{4}{|c|}{ Rural } & \multicolumn{4}{|c|}{ Total } \\
\hline & \multicolumn{2}{|c|}{1988} & \multicolumn{2}{|c|}{1998} & \multicolumn{2}{|c|}{1988} & \multicolumn{2}{|c|}{1998} & \multicolumn{2}{|c|}{1988} & \multicolumn{2}{|c|}{1998} \\
\hline & $000 \mathrm{~s}$ & $\%$ & $000 \mathrm{~s}$ & $\%$ & $000 \mathrm{~s}$ & $\%$ & $000 \mathrm{~s}$ & $\%$ & $000 \mathrm{~s}$ & $\%$ & $000 \mathrm{~s}$ & $\%$ \\
\hline \multicolumn{13}{|l|}{ Male } \\
\hline $15 \quad 19$ & 1185 & 11.1 & 1537 & 12.0 & 1576 & 11.2 & 2437 & 13.8 & 2761 & 11.1 & 3974 & 13.1 \\
\hline $20 \_24$ & 1056 & 9.9 & 1357 & 10.6 & 1328 & 9.4 & 1726 & 9.8 & 2384 & 9.6 & 3083 & 10.1 \\
\hline $15 \_24$ & 2241 & 21.0 & 2894 & 22.6 & 2904 & 20.6 & 4163 & 23.6 & 5145 & 20.7 & 7057 & 23.2 \\
\hline \multicolumn{13}{|l|}{ Female } \\
\hline 15_19 & 1103 & 10.4 & 1410 & 11.0 & 1516 & 10.7 & 2303 & 13.4 & 2619 & 10.6 & 3713 & 12.4 \\
\hline $20 \quad 24$ & 1018 & 9.6 & 1162 & 9.1 & 1170 & 8.3 & 1475 & 8.6 & 2188 & 8.8 & 2637 & 8.8 \\
\hline $15 \_24$ & 2121 & 20.0 & 2572 & 20.1 & 2686 & 19.0 & 3778 & 22.0 & 4807 & 19.4 & 6350 & 21.2 \\
\hline \multicolumn{13}{|l|}{ Total } \\
\hline 15_19 & 2288 & 10.7 & 2947 & 11.5 & 3092 & 10.9 & 4740 & 13.6 & 5380 & 10.9 & 7687 & 12.7 \\
\hline $20 \_24$ & 2074 & 9.7 & 2519 & 9.8 & 2498 & 8.8 & 3201 & 9.2 & 4572 & 9.2 & 5720 & 9.5 \\
\hline $15 \quad 24$ & 4362 & 20.4 & 5466 & 21.3 & 5590 & 19.7 & 7941 & 22.8 & 9952 & 20.1 & 13407 & 22.2 \\
\hline
\end{tabular}

Source: Assaad, R. (1999)

Table A2. Labor Force Participation of Youth (ages 15-24) in Egypt, by Urban/Rural Residence and School Status, 1998

\begin{tabular}{|c|c|c|c|c|c|c|}
\hline \multirow[b]{2}{*}{ School status } & \multicolumn{3}{|c|}{ Urban } & \multicolumn{3}{|c|}{ Rural } \\
\hline & Male & Female & Total & Male & Female & Total \\
\hline Never been & 1.34 & 4.71 & 2.93 & 7.21 & 24.93 & 15.65 \\
\hline In the past & 48.4 & 45.8 & 47.18 & 52.37 & 44.62 & 48.68 \\
\hline at school & 50.26 & 49.49 & 49.9 & 40.42 & 30.44 & 35.67 \\
\hline Total & 100.0 & 100.0 & 100.0 & 100.0 & 100.0 & 100.0 \\
\hline $\mathrm{N}$ & 1709 & 1523 & 3232 & 1011 & 919 & 1930 \\
\hline
\end{tabular}

Source: ELMS, 1998

Table A3. Household Size of Youth (ages 15 to 24) in the Labor Force in Egypt, by Sex, 1998

\begin{tabular}{lccc}
\hline & Male & Female & Total \\
\hline Small 1_4 & 17.2 & 22.7 & 18.8 \\
Medium 5_7 & 47.5 & 49.7 & 48.1 \\
Large $>=8$ & 35.3 & 27.5 & 33.1 \\
Total & 100.0 & 100.0 & 100.0 \\
N (weighted) & 1136 & 460 & 1596 \\
\hline Source: & &
\end{tabular}

Source: ELMS, 1998 
Table A4. Labor Force Participation of Youth (ages 15 to 24) in Egypt, by Sex and Household Size, 1998

\begin{tabular}{|c|c|c|c|c|c|c|c|c|c|}
\hline & $\begin{array}{r}\text { out of } \\
\text { LF }\end{array}$ & $\begin{array}{l}\text { Male } \\
\text { in } L F\end{array}$ & Total & $\begin{array}{r}\text { out of } \\
\text { LF }\end{array}$ & $\begin{array}{c}\text { Female } \\
\text { in LF }\end{array}$ & Total & $\begin{array}{r}\text { out of } \\
\text { LF }\end{array}$ & $\begin{array}{l}\text { Total } \\
\text { in LF }\end{array}$ & Total \\
\hline Small 1_4 & 56.3 & 43.7 & 100.0 & 79.6 & 20.4 & 100.0 & 68.7 & 31.3 & 100.0 \\
\hline Medium 5_7 & 61.4 & 38.7 & 100.0 & 80.1 & 20.0 & 100.0 & 69.8 & 30.2 & 100.0 \\
\hline Large $>=8$ & 50.0 & 50.0 & 100.0 & 82.5 & 17.5 & 100.0 & 65.4 & 34.6 & 100.0 \\
\hline Total & 57.1 & 43.0 & 100.0 & 80.7 & 19.3 & 100.0 & 68.2 & 31.8 & 100.0 \\
\hline $\mathrm{N}$ (weighted) & 1561 & 1176 & 2737 & 1967 & 471 & 2438 & 3531 & 1644 & 5175 \\
\hline
\end{tabular}

Source: ELMS, 1998

Table A5. Distribution of Youth Wage Workers (15-24) in Egypt, by Sex and Sector, 1988-1998

\begin{tabular}{lcccccccc}
\hline & & $\mathbf{1 9 8 8}$ & & & & $\mathbf{1 9 9 8}$ & \\
& Male & Female & Total & & Male & Female & Total \\
\hline Public & 12.5 & 43.9 & 19.8 & & 13.3 & 41.2 & 18.2 \\
Private & 87.5 & 56.1 & 80.2 & & 86.6 & 58.2 & 81.7 \\
Other & - & - & - & & 0.1 & 0.6 & 0.2 \\
Total & 100.0 & 100.0 & 100.0 & & 100.0 & 100.0 & 100.0 \\
N (weighted) & 717 & 218 & 935 & & 670 & 140 & 810 \\
\hline
\end{tabular}

Source: LFSS, 1988, ELMS, 1998

Table A6. Distribution of Youth Wage Workers (15-24) in the Private Sector in Egypt, by Economic Activity and Sex, 1988-1998

\begin{tabular}{|c|c|c|c|c|c|c|}
\hline & \multicolumn{3}{|c|}{1988} & \multicolumn{3}{|c|}{1998} \\
\hline & Male & Female & Total & Male & Female & Total \\
\hline Agriculture & 25.4 & 31.9 & 26.4 & 16.5 & 16.1 & 16.4 \\
\hline Mining & 0.6 & 0.0 & 0.5 & - & - & - \\
\hline Manufacturing & 27.3 & 21.7 & 26.4 & 26.8 & 30.0 & 27.2 \\
\hline Elect & 0.2 & 0.0 & 0.1 & - & - & - \\
\hline Construction & 21.2 & 0.0 & 17.8 & 22.4 & 1.3 & 19.8 \\
\hline Trade & 14.5 & 27.0 & 16.5 & 15.3 & 30.4 & 17.2 \\
\hline Transport & 2.9 & 1.8 & 2.8 & 7.2 & 0.0 & 6.3 \\
\hline Finance & 0.3 & 1.0 & 0.4 & 1.4 & 4.9 & 1.8 \\
\hline Services & 7.6 & 16.7 & 9.1 & 10.5 & 17.4 & 11.4 \\
\hline Total & 100.0 & 100.0 & 100.0 & 100.0 & 100.0 & 100.0 \\
\hline $\mathrm{N}$ (weighted) & 622 & 118 & 740 & 564 & 80 & 644 \\
\hline
\end{tabular}

Source: LFSS, 1988, ELMS, 1998 
Table A7. Distribution of Youth Wage Workers (15-24) in the Government Sector in Egypt, by Economic Activity and Sex, 1988-1998

\begin{tabular}{|c|c|c|c|c|c|c|}
\hline & \multicolumn{3}{|c|}{1988} & \multicolumn{3}{|c|}{1998} \\
\hline & Male & Female & Total & Male & Female & Total \\
\hline Agriculture & 7.2 & 5.5 & 6.2 & 0.0 & 5.8 & 2.8 \\
\hline Manufacturing & 7.7 & 1.4 & 4.1 & 2.7 & 0.0 & 1.4 \\
\hline Trade & 0.0 & 1.8 & 1.0 & 4.6 & 0.0 & 2.4 \\
\hline Transport & 7.6 & 2.5 & 4.7 & 1.2 & 0.0 & 0.6 \\
\hline Finance & 1.3 & 6.6 & 4.3 & 18.1 & 1.4 & 10.1 \\
\hline Services & 76.2 & 82.3 & 79.7 & 73.4 & 92.7 & 82.7 \\
\hline Total & 100.0 & 100.0 & 100.0 & 100.0 & 100.0 & 100.0 \\
\hline $\mathrm{N}$ (weighted) & 51 & 69 & 120 & 66 & 62 & 128 \\
\hline
\end{tabular}

Source: LFSS, 1988, ELMS, 1998

Table A8. Distribution of Youth Wage Workers (ages 15-24) in the Government Sector in Egypt, by Occupation and Sex, 1988-1998

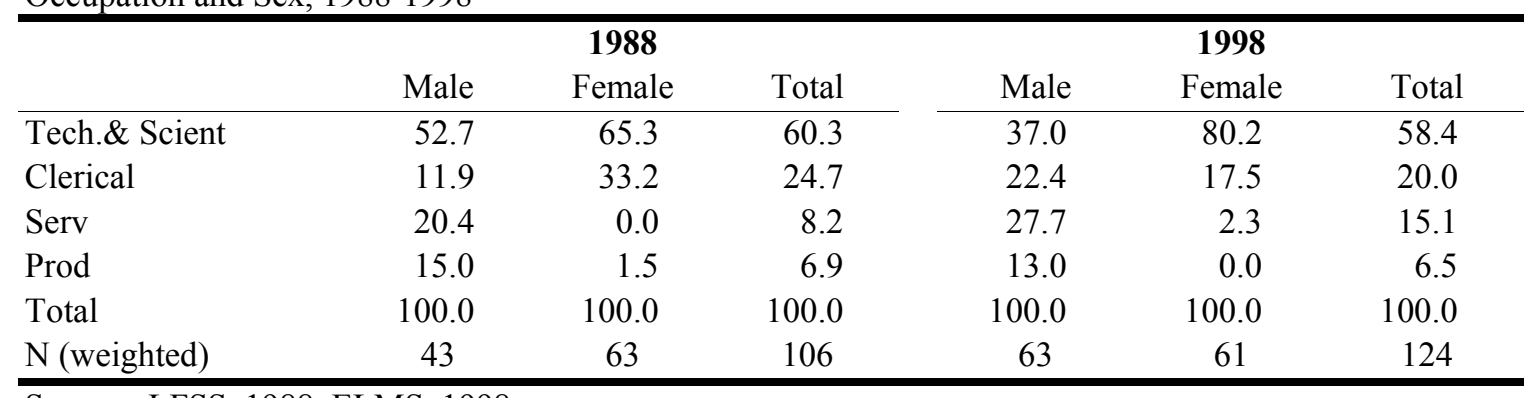

Source: LFSS, 1988, ELMS, 1998 


\section{References}

Adolescence and Social Change in Egypt (ASCE). 1997. Dataset.

Al-Bassusi, Nagah. 1997. Personal communication.

Al-Iqtissadi 1998. “Mashru' Qanun Al’Amal” (New Labor Law Project), November. Cairo, Egypt (Arabic).

Amin, S., I. Diamond, R.T. Naved and M. Newby . 1997. "Transition to Adulthood of Female Factory Workers: Some Evidence from Bangladesh," Policy Research Division Working Papers No. 102. New York: Population Council.

Anand, S. 1994. "Population, Well-being, and Freedom” in Population Policies Reconsidered: Health, Empowerment, and Rights edited by G. Sen, A. Germain and L.C. Chen. Boston: Harvard University Press.

Adolescence and Social Change in Egypt (ASCE). 1999. "Transitions to Adulthood: A national survey of Egyptian adolescents." New York: Population Council.

Assaad, R. 1995. "The Effects of Public Sector Hiring \& Compensation Policies on the Egyptian Labor Market" Working Paper No. 9517, Working Paper Series, The Economic Research Forum for the Arab Countries, Iran and Turkey. Cairo: Egypt.

Assaad, R. 1997. "The Employment Crisis in Egypt: Current Trends and Future Prospects" Research in Middle East Economics, Volume 2, JAI Press Inc., USA.

Assaad, R. 1999. "The Transformation of the Egyptian Labor Market: 1988-1998" presented at the Conference on Labor Markets and Human Resource Development in Egypt, November 29-30, 1999. Cairo: Egypt.

Assaad, R. and G. Barsoum. 1999. "Egypt Labor Market Survey 1998 - Report on the Data Collection and Preparation" presented to Economic Policy Initiative Consortium (EPIC), Cairo: Egypt.

Assaad, R., F. El-Hamidi and A. Ahmed. 1999. "The Determinants of Employment Status in Egypt" Report presented to the International Food Policy Research Institute, Washington, DC, USA.

Chambers, R. 1995. "Poverty and livelihoods: Whose Reality Counts?” IDS Discussion Paper 342, Brighton, United Kingdom: Institute of Development Studies

Collier, P. 1994. "A Theoretical Framework and the Africa Experience" in Labor Markets in an Era of Adjustment, Vol. 1, Issues Papers, edited by S. Horton, R. Kanbur, and D. Mazumdar, EDI Development Studies, Washington: The World Bank.

Democratic Development Group. 1998. "Huwar hawl mashro' qanoon al'a'mal almuwahad" No. 7, 16027/98, 977-5797-15-2, Cairo: Yusif Kamal Printing House (Arabic). 
Development Economic Policy Reform Analysis Project, Nathan Associates Inc. 1997. "Egypt: A Comparative Study of Foreign Direct Investment Climates" Final Report submitted to USAID, Cairo, Egypt and The Ministry of Economy and International Cooperation, Government of Egypt. August 20, 1997.

Diwan, I. And M. Walton. 1996. "Opening Up and Distribution in the Middle East \& North Africa: The Poor, The Unemployed \& the Public Sector" Working Paper Series \#9616, Cairo: The Economic Research Forum For the Arab Countries, Iran and Turkey.

Egypt Demographic Health Survey (EDHS). 1995. Cairo, Egypt.

El-Kogali, S. 1997. "Private Sector Development in MENA: New opportunities and challenges". Background paper for Economic Trends in the MENA Region, Economic Research Forum, Cairo, Egypt.

El-Kogali, S. 1997a. "Privatization in the MENA Region". Background paper for Economic Trends in the MENA Region, Economic Research Forum, Cairo, Egypt.

Handoussa, H. 1989. 'Egypt's Investment Strategy, Policies and Performane since the Infitah' paper presented to Seminar on Investment Policies in Arab Countries, Kuwait, 11-13 December, 1989. Arab Fund for Economic and Social Development and Arab Monetary Fund.

Handoussa, H. and G. Potter. 1992. “Egypt's Informal Sector: Engine of Growth?” Paper presented at the MESA Conference, Portland, October 28-31, 1992.

Handoussa, H. 1994. "The Role of the State: The Case of Egypt." ERF Working Paper Series No. 9404. The Economic Research Forum Iran \& Turkey.

Hoodfar, H. 1997. Between Marriage and the Market: Intimate Politics and Survival in Cairo, Berkeley: University of California Press, USA.

Kabeer, N. 1991. "Cultural Dopes or Rational Fools? Women and Labor Supply in the Bangladesh Garment Industry" in The European Journal of Development Research, 3(1), London: Frank Cass and Company Ltd.

Karshenas, M. 1994. "Structural Adjustment and Employment in the Middle East and North Africa" ERF Working Paper Series No. 9420, Cairo: The Economic Research Forum for the Arab Countries, Iran \& Turkey.

Law No. 137 of 1981 'Labor Law' (Arabic). 
Lee, S. 1993. "Transitions to adulthood: A national survey of adolescents in Egypt." Project Summary of the Adolescence and Social Change in Egypt survey. New York: Population Council.

Mahmud, S. and A.M. Johnston. 1994. “Women's Status, Empowerment, and Reproductive Outcomes" in G. Sen, A. Germain and L.C. Chen (eds.), Population Policies Reconsidered: Health, Empowerment, and Rights. Boston: Harvard University Press.

Moghadam, V.M. 1993. Modernizing Women: Gender and Social Change in the Middle East, Lynne Reiner Publishers, Inc.

Moghadam, V.M. 1998. "Egypt: 'Yes It Can Get Worse Than This' - Economic Reform and Women's Employment" in Women, Work, and Economic Reform in the Middle East and North Africa, USA: Lynne Rienner Publishers, Inc.

Nawar, L, C.B. Lloyd, B. Ibrahim. 1995. "Women's Autonomy and Gender Roles in Egyptian Families" in C.M. Obermeyer (ed.) Family, Gender, and Population in the Middle East: Policies in Context. Cairo: The American University in Cairo Press.

Pearsall, J. and B. Trumble. 1995. The Oxford English Reference Dictionary, UK.

Posusney, M.P. 1995. "Labor and Privatization in Egypt: Recent Development and Future Scenarios" in Hans Hopfinger, Justus Perthesverlag Gotha (eds.) Economic Liberalization and Privatization in Socialist Arab Countries: Algeria, Egypt and Yemen as Examples.

Radwan, S. 1998. "Towards Full Employment: Egypt into the $21^{\text {st }}$ Century", The Egyptian Center for Economic Studies (ECES) Distinguished Lecture Series 10. Cairo.

Rashad, H. and Z. Khadr. 1998. "The Demography of the Arab Region: New Challenges and Opportunities" paper presented at the conference on Population Challenges in the Middle East \& North Africa: Towards the Twenty First Century, 2-4 November, 1998.

Safa, H.I. 1981. "Runaway Shops and Female Employment: The Search for Cheap Labor" in Signs: Journal of Women in Culture and Society Vol. 7, No. 2 , Chicago: The University of Chicago.

Standing, G. 1989. “Global Feminization through Flexible Labor,” World Development, 17(7).

The State Information Service, "The 1980 Constitution of The Arab Republic of Egypt, After the Amendments Ratified in the May 22, 1980 Referendum," Cairo: Al-Ahram Press.

United Nations Conference on Trade and Development (UNCTAD). 1999. Investment Policy Review: Egypt. Geneva: United Nations. 
United Nations Development Programme (UNDP). 1996. Egypt Human Development Report. Cairo

World Bank. 1997. "Arab Republic of Egypt Country Economic Memorandum Working Papers Annex," Volume 3, Report No. 16207-EGT, World Bank Resident Mission in Egypt, Middle East and North Africa Region. 